\title{
Osimertinib in EGFR-Mutated Lung Cancer: A Review of the Existing and Emerging Clinical Data
}

\author{
Chung-Shien Lee $\mathbb{I D}^{1,2}$ \\ Matthew Milone ${ }^{3}$ \\ Nagashree Seetharamu $\mathbb{D}^{2}$ \\ 'Department of Clinical Health \\ Professions, St. John's University, Queens, \\ NY, USA; ${ }^{2}$ Division of Medical Oncology \\ and Hematology, Northwell Health \\ Cancer Institute, Lake Success, NY, USA; \\ ${ }^{3}$ Pharmacy Department, Long Island \\ Jewish Medical Center, New Hyde Park, \\ NY, USA
}

\begin{abstract}
The use of epidermal growth factor receptor $(E G F R)$ inhibitors such as osimertinib has improved outcomes and quality of life for patients with EGFR-mutated non-small cell lung cancer (NSCLC). Osimertinib has become the preferred EGFR tyrosine kinase inhibitor (TKIs) for patients with these mutations after demonstrating superior efficacy compared to first generation EGFR TKIs, such as erlotinib and gefitinib. More recently osimertinib has also shown to be beneficial in patients with resectable NSCLC harboring $E G F R$ mutations irrespective of whether they received adjuvant chemotherapy or not. The drug is now FDA approved in this setting. With osimertinib being used more commonly in earlier stage and front-line settings, we are more likely to see patients who develop resistance to this drug. The aim of this review is to provide a comprehensive review of the data with osimertinib in EGFR mutation positive NSCLC, potential resistance mechanisms and an overview of key ongoing clinical trials.
\end{abstract}

Keywords: non-small cell lung cancer, epidermal growth factor receptor, tyrosine kinase inhibitor, osimertinib

\section{Introduction}

Lung cancer is one of the most prevalent cancers developed in men and women throughout the world. Lung cancer remains the leading cause of cancer related mortality, accounting for $23 \%$ in males and $22 \%$ in females. Lifetime probability of developing lung cancer is estimated to be 1 in 15 and 1 and 17 in men and women, respectively. ${ }^{1}$ The overall five-year survival rate for lung cancer has been decreasing over the last few decades, yet it still remains the second highest of all cancer diagnosis' at $15 \%$. $^{1,2}$

Lung cancer is categorized into two large types: small-cell lung carcinoma and non-small cell lung carcinoma (NSCLC) (which encompasses histologies such as adenocarcinoma, squamous cell carcinoma, and large cell carcinoma). ${ }^{1}$ NSCLC accounts for approximately $85 \%$ of all lung cancer cases. ${ }^{3}$ Adenocarcinoma, is the most prevalent histological subtype originating from mucus-secreting cells, in both smokers and non-smokers. Adenocarcinoma is a heterogeneous disease further stratified by molecular driver mutations as detailed below. Epidermal growth factor receptor $(E G F R)$ was one of the first discovered actionable driver mutations. ${ }^{4}$

Treatment for NSCLC has been evolving over the last few decades. The landmark trial in 2003, analyzed four chemotherapy platinum-based doublets in patients with untreated advanced NSCLC and concluded no survival difference between the regimens analyzed with median overall survival (OS) in all arms being less than 12
Correspondence: Nagashree Seetharamu Email nseetharamu@northwell.edu 
months. ${ }^{5}$ The paradigm-changing IPASS study by Mok et al, published in 2009 demonstrated superior efficacy of gefitinib, an oral tyrosine kinase inhibitor (TKI) over platinum doublet chemotherapy in front-line setting for treatment of NSCLC in never or former light-smokers of Asian ethnicity. ${ }^{6}$ Exploratory analysis of efficacy based on EGFR mutation showed that the progression-free survival (PFS) was 9.8 for patients who were treated with gefitinib vs 6.4 months for those who were treated with carboplatin and paclitaxel (hazard ratio [HR] 0.48, $\mathrm{p}<0.001$ ). PFS was higher in patients treated with chemotherapy compared to those treated with gefitinib in $E G F R$ wild-type cohort highlighting the importance of EGFR mutation testing in NSCLC. ${ }^{6}$ This led to further investigation of the use of EGFR TKIs in patients with EGFR mutated advanced NSCLC. NEJ002 was a randomized Phase 3 trial comparing gefitinib to carboplatin and paclitaxel in this patient population. Gefitinib demonstrated an improvement in PFS with a median of 10.8 months compared to 5.4 months in the chemotherapy group $(\mathrm{HR}=0.32, \mathrm{p}<0.001){ }^{7}$ In a similar study design, OPTIMAL compared erlotinib to carboplatin and paclitaxel and also demonstrated a PFS improvement with an EGFR TKI compared to chemotherapy (13.1 vs 4.6 months; $\mathrm{HR}=0.16, \mathrm{p}<0.0001$ ). Both of these studies did not show a statistically significant improvement in OS. ${ }^{8,9}$

$E G F R$ is a cell-surface tyrosine kinase receptor belonging to the erbB family which includes erbB1 (EGFR), erbB2 (HER2), erbB3, and erbB4. Ligand binding is necessary to activate a wild-type $E G F R$, inducing a conformational change to its active state. ${ }^{10}$ Receptor activation subsequently results in autophosphorylation of tyrosine residues within the tail of the EGFR, forming a large protein complex that can induce downstream signaling. ${ }^{10}$ Downstream pathways include: Ras/Raf/(Ras/ $M A P K),(P I 3 K / A K T)$, and STAT, all leading to rapid cell survival, proliferation, and cellular migration. ${ }^{10}$ In NSCLC with EGFR mutations, there is constant ligandindependent activation and proliferation within the rapidly dividing cells. Mutations within the EGFR gene occur in approximately $15 \%$ of NSCLC adenocarcinomas, and in Asian populations, the incidence has been reported at roughly $62 \%{ }^{11}$ Genetic mutations of EGFR typically involve single nucleotide variation (SNV), insertion, deletion, and copy number variations. Genetic variations are frequently seen in exons $18-21$, with therapeutic response to TKI noted primarily in NSCLC with exon 19 and 21 mutations. The most common mutations within EGFR are the deletion of amino acids at 747-750 of exon 19 (19Del) and L858R of exon 21, discovered in $33.1 \%$ and $40.9 \%$ of the patient population, respectively. ${ }^{12}$

Multiple TKIs have shown activity in EGFR mutation positive NSCLC. The agents are categorized as first generation reversible agents (gefitinib, icotinib and erlotinib), second generation irreversible agents (afatinib and dacomitinib) and third generation agents with activity against secondary resistance mutation (osimertinib) and are summarized in Table $1 .^{6-9,13-32}$ Gefitinib, erlotinib, afatinib, dacomitinib and osimertinib are all approved by United States Food and Drug Administration (US FDA) for use in front-line setting for EGFR mutation-positive NSCLC. ${ }^{33,34}$ Head-to-head comparison between first generation TKIs, gefitinib and erlotinib was performed in a phase 3 study and both drugs were noted to have similar efficacy and toxicity. ${ }^{35}$ Second generation agents, afatinib and dacomitinib have been shown to have superior efficacy than gefitinib in LUX-Lung-7 and the ARCHER1050 studies respectively. ${ }^{22,23,25,26}$ Afatinib had marginal improvement in PFS but no difference in OS when compared to gefitinib. ${ }^{22,23}$ Dacomitinib, on the other hand showed significant improvement in PFS as well as OS predominantly in the Asian population. ${ }^{25,26}$ However, both these agents had significantly increased toxicity compared to gefitinib.

\section{Osimertinib in Previously-Treated EGFR-Mutation Positive NSCLC Patients}

Acquired resistance to first or second generation EGFRTKIs is common and occurs approximately 10 months from initiation of therapy. ${ }^{36}$ The T790M substitution within exon 20 , is a leading contributor for resistance to first- and second-generation EGFR inhibitors in NSCLC. T790M mutations within exon 20 result in $60 \%$ of acquired resistance to EGFR-TKIs. ${ }^{37}$ Osimertinib is an oral, third generation $E G F R$-TKI, that was formulated to inhibit $E G F R$ with preferential activity against both sensitizing and T790M resistance mutations. Osimertinib provides benefit in patients with $\mathrm{T} 790 \mathrm{M}$ mutations by irreversibly targeting cysteine-797 residue in the ATP binding site of $E G F R$ kinase via a covalent bond formation. This results in selective inhibition of mutant $E G F R$ including T790M at a concentration that is nine-fold lower than wild-type $E G F R .^{37}$ Clinical trials of osimertinib began in 2013 and showed impressive anti-tumor activity 
Table I Select Epidermal Growth Factor Receptor Tyrosine Kinase Inhibitors Trials

\begin{tabular}{|c|c|c|c|c|c|c|c|c|}
\hline Trial & Phase & $\mathbf{N}$ & Patient Population & Intervention & $\begin{array}{l}\text { Median } \\
\text { Follow-Up } \\
\text { (Median, } \\
\text { Months) }\end{array}$ & $\begin{array}{l}\text { PFS (Median, } \\
\text { Months) }\end{array}$ & $\begin{array}{l}\text { OS (Median, } \\
\text { Months) }\end{array}$ & ORR (\%) \\
\hline IPASS $^{6,13}$ & 3 & $\begin{array}{l}1217 \\
261 \\
(E G F R+)\end{array}$ & $\begin{array}{l}\text { Treatment naïe } \\
\text { patients in East Asia } \\
\text { with advanced } \\
\text { adenocarcinoma and } \\
\text { who were } \\
\text { nonsmokers or } \\
\text { former light smokers }\end{array}$ & $\begin{array}{l}\text { Gefitinib } 250 \mathrm{mg} / \\
\text { day vs carboplatin } \\
\text { plus paclitaxel }\end{array}$ & 17.0 & $\begin{array}{l}\text { EGFR+ group: } \\
9.5 \text { vs } 6.3 ; \\
H R=0.48(0.36- \\
0.64) ; p<0.001 \\
\text { EGFR- group: } \\
\text { I.5 vs } 5.5 ; \\
\text { HR=2.85 }(2.05- \\
3.98) ; p<0.001\end{array}$ & $\begin{array}{l}18.8 \text { vs } 17.4 ; \\
H R=0.90(0.79- \\
1.02) ; p=0.109\end{array}$ & 71.2 vs 47.3 \\
\hline $\begin{array}{l}\text { WJTOG- } \\
3405^{14,15}\end{array}$ & 3 & 172 & $\begin{array}{l}\text { Chemotherapy naïe } \\
\text { patients with stage } \\
\text { IIIB/IV NSCLC or } \\
\text { post-operative } \\
\text { recurrence harboring } \\
\text { EGFR mutations }\end{array}$ & $\begin{array}{l}\text { Gefitinib } 250 \mathrm{mg} / \\
\text { day or cisplatin } \\
\text { plus docetaxel }\end{array}$ & 59.1 & $\begin{array}{l}9.2 \text { vs } 6.3 \\
H R=0.49(0.34 \\
0.71) ; p<0.0001\end{array}$ & $\begin{array}{l}34.8 \text { vs } 37.3 ; \\
H R=I .252 \\
(0.883-1.775)\end{array}$ & 62.1 vs 32.2 \\
\hline $\begin{array}{l}\text { First-SIGNAL } \\
16\end{array}$ & 3 & 42 & $\begin{array}{l}\text { Stage IIIB/IV } \\
\text { adenocarcinoma }\end{array}$ & $\begin{array}{l}\text { Gefitinib } 250 \mathrm{mg} / \\
\text { day vs } \\
\text { gemcitabine plus } \\
\text { cisplatin }\end{array}$ & 35 & $\begin{array}{l}5.8 \text { vs } 6.4 ; \\
H R=1.198 \\
(0.944-1.520) ; \\
P=0.138\end{array}$ & $\begin{array}{l}22.3 \text { vs } 22.9 ; \\
H R=0.932 \\
(0.7 \mid 6-1.213) ; \\
p=0.604\end{array}$ & 84.6 vs 37.5 \\
\hline NEJ002 ${ }^{7}$ & 3 & 230 & $\begin{array}{l}\text { Treatment naive } \\
\text { EGFR mutated } \\
\text { advanced NSCLC }\end{array}$ & $\begin{array}{l}\text { Gefitinib } 250 \mathrm{mg} / \\
\text { day vs carboplatin } \\
\text { plus paclitaxel }\end{array}$ & 704 days & $\begin{array}{l}\text { I0.8 vs } 5.4 ; \\
H R=0.322 \\
(0.236-0.438) ; \\
P<0.001\end{array}$ & $\begin{array}{l}27.7 \text { vs } 26.6 ; \\
H R=0.887 \\
(0.634-I .24 I) ; \\
P=0.483\end{array}$ & 73.7 vs 30.7 \\
\hline EURTAC $^{17}$ & 3 & 173 & $\begin{array}{l}\text { Treatment naïe } \\
\text { EGFR mutated } \\
\text { advanced NSCLC }\end{array}$ & $\begin{array}{l}\text { Erlotinib } 150 \mathrm{mg} / \\
\text { day vs } 3 \text {-week } \\
\text { cycles of standard } \\
\text { IV chemotherapy }\end{array}$ & 18.9 vs 14.4 & $\begin{array}{l}9.7 \text { vs } 5.2 \\
H R=0.37(0.25- \\
0.54) ; p<0.000 I\end{array}$ & $\begin{array}{l}19.3 \text { vs } 19.5 ; \\
H R=1.04(0.65- \\
1.68) ; p=0.87\end{array}$ & 53 vs 15 \\
\hline OPTIMAL 8,9 & 3 & 154 & $\begin{array}{l}\text { EGFR mutated stage } \\
\text { IIIB/IV NSCLC }\end{array}$ & $\begin{array}{l}\text { Erlotinib } 150 \mathrm{mg} / \\
\text { day vs } \\
\text { gemcitabine plus } \\
\text { carboplatin }\end{array}$ & 25.9 & $\begin{array}{l}13.1 \text { vs } 4.6 ; \\
H R=0.16(0.10- \\
0.26) ; p<0.0001\end{array}$ & $\begin{array}{l}22.8 \text { vs } 27.2 ; \\
H R=1.19(0.83- \\
I .71) ; p=0.2663\end{array}$ & 83 vs 36 \\
\hline ENSURE $^{18}$ & 3 & 217 & $\begin{array}{l}\text { EGFR mutated stage } \\
\text { IIIB/IV NSCLC }\end{array}$ & $\begin{array}{l}\text { Erlotinib } 150 \mathrm{mg} / \\
\text { day vs } \\
\text { gemcitabine and } \\
\text { cisplatin up to } 4 \\
\text { cycles }\end{array}$ & 28.9 vs 27.1 & $\begin{array}{l}\text { II } .0 \text { vs } 5.5 ; \\
H R=0.34(0.22- \\
0.51) ; p<0.0001\end{array}$ & $\begin{array}{l}26.3 \text { vs } 25.5 ; \\
H R=0.91(0.63- \\
1.31) ; p=0.607\end{array}$ & 62.7 vs 33.6 \\
\hline $\begin{array}{l}\text { LUX-LUNG I } \\
19\end{array}$ & $2 B / 3$ & 585 & $\begin{array}{l}\text { EGFR mutated Stage } \\
\text { IIIB/IV NSCLC who } \\
\text { had received I or } 2 \\
\text { previous } \\
\text { chemotherapy } \\
\text { regimens and had } \\
\text { disease progression } \\
\text { after I } 2 \text { weeks of } \\
\text { treatment with } \\
\text { erlotinib or gefitinib }\end{array}$ & $\begin{array}{l}\text { Afatinib } 40 \mathrm{mg} / \\
\text { day vs placebo }\end{array}$ & NR & $\begin{array}{l}3.3 \text { vs I.I; } \\
H R=0.38(0.3 \mathrm{I}- \\
0.48) ; p<0.000 \mathrm{I}\end{array}$ & $\begin{array}{l}10.8 \text { vs } 12.0 ; \\
H R=1.08(0.86- \\
1.35) ; p=0.74\end{array}$ & NR \\
\hline
\end{tabular}


Table I (Continued).

\begin{tabular}{|c|c|c|c|c|c|c|c|c|}
\hline Trial & Phase & $\mathbf{N}$ & Patient Population & Intervention & $\begin{array}{l}\text { Median } \\
\text { Follow-Up } \\
\text { (Median, } \\
\text { Months) }\end{array}$ & $\begin{array}{l}\text { PFS (Median, } \\
\text { Months) }\end{array}$ & $\begin{array}{l}\text { OS (Median, } \\
\text { Months) }\end{array}$ & ORR (\%) \\
\hline $\begin{array}{l}\text { LUX-LUNG3 } \\
20\end{array}$ & 3 & 345 & $\begin{array}{l}\text { EGFR mutated stage } \\
\text { IIIB/IV NSCLC }\end{array}$ & $\begin{array}{l}\text { Afatinib } 40 \mathrm{mg} / \\
\text { day vs up to } 6 \\
\text { cycles of cisplatin } \\
\text { plus pemetrexed } \\
\text { chemotherapy }\end{array}$ & 16.4 & $\begin{array}{l}\text { II.I vs } 6.9 ; \\
H R=0.58(0.43- \\
0.78) ; p=0.001\end{array}$ & $\begin{array}{l}28.2 \text { vs } 28.2 ; \\
H R=0.88(0.66- \\
1.17) ; p=0.39\end{array}$ & 56.1 vs 22.6 \\
\hline $\begin{array}{l}\text { LUX-LUNG6 } \\
21\end{array}$ & 3 & 364 & $\begin{array}{l}\text { Treatment naive } \\
\text { EGFR mutated } \\
\text { advanced NSCLC }\end{array}$ & $\begin{array}{l}\text { Afatinib } 40 \mathrm{mg} / \\
\text { day vs } \\
\text { gemcitabine and } \\
\text { cisplatin for up to } \\
6 \text { cycles }\end{array}$ & 16.6 & $\begin{array}{l}\text { II.0 vs } 5.6 \\
H R=0.28(0.20 \\
0.39) ; p<0.000 I\end{array}$ & $\begin{array}{l}23.1 \text { vs } 23.5 ; \\
H R=0.93(0.72- \\
1.22) ; p=0.61\end{array}$ & 66.9 vs 23.0 \\
\hline $\begin{array}{l}\text { LUX-LUNG7 } \\
22,23\end{array}$ & $2 B$ & 319 & $\begin{array}{l}\text { EGFR mutated stage } \\
\text { IIIB/IV NSCLC }\end{array}$ & $\begin{array}{l}\text { Afatinib } 40 \mathrm{mg} / \\
\text { day vs gefitinib } \\
250 \mathrm{mg} / \text { day }\end{array}$ & 42.6 & $\begin{array}{l}\text { II.0 vs I0.9; } \\
H R=0.73(0.57- \\
0.95) ; p=0.017\end{array}$ & $\begin{array}{l}27.9 \text { vs } 24.5 ; \\
H R=0.86(0.66- \\
I .12) ; p=0.258\end{array}$ & 70 vs 56 \\
\hline$\underset{24}{\text { LUX-LUNG8 }}$ & 3 & 795 & $\begin{array}{l}\text { Stage IIIB/IV SCLC } \\
\text { after progression of } \\
>4 \text { cycles of platinum- } \\
\text { based chemotherapy }\end{array}$ & $\begin{array}{l}\text { Afatinib } 40 \mathrm{mg} / \\
\text { day vs erlotinib } \\
150 \mathrm{mg} / \text { day }\end{array}$ & 18.4 & $\begin{array}{l}2.4 \text { vs I.9; } \\
H R=0.82(0.68- \\
I .00) ; p=0.0427\end{array}$ & $\begin{array}{l}7.9 \text { vs } 6.8 \\
H R=0.8 I(0.69- \\
0.95) ; p=0.0077\end{array}$ & 22 vs II \\
\hline $\begin{array}{l}\text { ARCHER } \\
1050^{25,26}\end{array}$ & 3 & 452 & $\begin{array}{l}\text { Treatment naïe } \\
\text { EGFR mutated } \\
\text { advanced NSCLC }\end{array}$ & $\begin{array}{l}\text { Dacomitinib } \\
45 \mathrm{mg} / \text { day vs } \\
\text { gefitinib } 250 \mathrm{mg} / \\
\text { day }\end{array}$ & 31.1 & $\begin{array}{l}\text { I4.7 vs } 9.2 \\
H R=0.59(0.47- \\
0.74) ; p<0.0001\end{array}$ & $\begin{array}{l}34.1 \text { vs } 26.8 \\
H R=0.760 \\
(0.582-0.993)\end{array}$ & 74.9 vs 71.6 \\
\hline $\begin{array}{l}\text { ARCHER } \\
1009^{27}\end{array}$ & 3 & 878 & $\begin{array}{l}\text { Locally advanced or } \\
\text { metastatic NSCLC, } \\
\text { progression after I-2 } \\
\text { previous regimens of } \\
\text { chemotherapy }\end{array}$ & $\begin{array}{l}\text { Dacomitinib } \\
45 \mathrm{mg} / \text { day vs } \\
\text { erlotinib } 150 \mathrm{mg} / \\
\text { day }\end{array}$ & 7.1 & $\begin{array}{l}2.6 \text { vs } 2.6 ; \\
H R=0.94 I \\
(0.802-I .104) ; \\
p=0.229\end{array}$ & $\begin{array}{l}7.9 \text { vs } 8.4 ; \\
H R=1.079 \\
(0.914-1.274) ; \\
p=0.817\end{array}$ & 11.0 vs 8.0 \\
\hline AURA $^{28}$ & 3 & 419 & $\begin{array}{l}\text { T790M-positive } \\
\text { advanced NSCLC } \\
\text { with disease } \\
\text { progression after } \text { I }^{\text {st }} \\
\text { line EGFR TKI therapy }\end{array}$ & $\begin{array}{l}\text { Osimertinib } \\
80 \mathrm{mg} / \text { day vs } \\
\text { pemetrexed plus } \\
\text { either carboplatin } \\
\text { or cisplatin }\end{array}$ & 8.3 & $\begin{array}{l}\text { I0.I vs } 4.4 ; \\
H R=0.30(0.23- \\
0.4 I) ; p<0.00 I\end{array}$ & NR & 71 vs 31 \\
\hline FLAURA $^{29}$ & 3 & 556 & $\begin{array}{l}\text { Treatment naive } \\
\text { EGFR mutated } \\
\text { advanced NSCLC }\end{array}$ & $\begin{array}{l}\text { Osimertinib } \\
80 \mathrm{mg} / \text { day vs } \\
\text { standard EGFR } \\
\text { TKI either } \\
\text { gefitinib } 250 \mathrm{mg} / \\
\text { day or erlotinib } \\
150 \mathrm{mg} / \text { day }\end{array}$ & 29 & $\begin{array}{l}\text { I8.9 vs I0.2; } \\
H R=0.46(0.37- \\
0.57) ; p<0.001\end{array}$ & $\begin{array}{l}38.6 \text { vs } 31.8 ; \\
H R=0.80(0.64- \\
1.00) ; p=0.046\end{array}$ & 80 vs 76 \\
\hline ICOGEN $^{30}$ & 3 & 399 & $\begin{array}{l}\text { Previously treated } \\
\text { with one or more } \\
\text { platinum-based } \\
\text { chemotherapy } \\
\text { regimens with no } \\
\text { response }\end{array}$ & $\begin{array}{l}\text { Icotinib I25 mg } \\
\text { three times daily } \\
\text { vs gefitinib } \\
250 \mathrm{mg} \text { once daily }\end{array}$ & 24 & $\begin{array}{l}4.6 \text { vs } 3.4 ; \\
H R=0.84(0.67- \\
I .05) ; p=0.13\end{array}$ & $\begin{array}{l}13.3 \text { vs } 13.9 ; \\
H R=1.02(0.82- \\
I .27) ; p=0.57\end{array}$ & 27.6 vs 27.2 \\
\hline
\end{tabular}

(Continued) 
Table I (Continued).

\begin{tabular}{|c|c|c|c|c|c|c|c|c|}
\hline Trial & Phase & $\mathbf{N}$ & Patient Population & Intervention & $\begin{array}{l}\text { Median } \\
\text { Follow-Up } \\
\text { (Median, } \\
\text { Months) }\end{array}$ & $\begin{array}{l}\text { PFS (Median, } \\
\text { Months) }\end{array}$ & $\begin{array}{l}\text { OS (Median, } \\
\text { Months) }\end{array}$ & ORR (\%) \\
\hline CONVINCE ${ }^{31}$ & 3 & 285 & $\begin{array}{l}\text { EGFR mutated stage } \\
\text { IIIB/IV NSCLC }\end{array}$ & $\begin{array}{l}\text { Icotinib } 125 \mathrm{mg} \\
\text { three times daily } \\
\text { vs } 3 \text { week cycles } \\
\text { of chemotherapy } \\
\left(75 \mathrm{mg} / \mathrm{mg}^{2}\right. \\
\text { cisplatin plus } \\
500 \mathrm{mg} / \mathrm{m}^{2} \\
\text { pemetrexed on } \\
\text { Day I) }\end{array}$ & 39.6 & $\begin{array}{l}\mathrm{II} .2 \text { vs } 7.9 ; \\
\mathrm{HR}=0.6 \mathrm{I}(0.43- \\
0.87) ; \mathrm{p}=0.006\end{array}$ & $\begin{array}{l}30.5 \text { vs } 32.1 \\
P=0.8854)\end{array}$ & NR \\
\hline
\end{tabular}

Abbreviations: EGFR, epidermal growth factor receptor; NSCLC, non-small cell lung cancer; NR, Not reported; ORR, overall response rate; OS, overall survival; PFS, progression free survival; SCLC, small cell lung cancer; TKI, tyrosine kinase inhibitors.

in EGFR-mutated (EGFR-m) NSCLC, which had progressed on first generation EGFR TKI. ${ }^{28}$ The subsequent phase 3 AURA3 study further solidified the role of osimertinib in NSCLC patients who had developed T790M resistance mutation on first generation TKI by showing significantly improved efficacy in comparison to platinumpemetrexed regimen in this patient population. Patients enrolled in the study were assigned in a 2:1 ratio to receive either oral osimertinib ( $80 \mathrm{mg}$ once daily) or intravenous pemetrexed (500 mg per square meter of body-surface area) plus either carboplatin (AUC 5) or cisplatin (75 mg per square meter) every 3 weeks for 6 cycles; primary endpoint was investigator-assessed progression free survival. Results showed a longer PFS with osimertinib than combination chemotherapy (10.1 months vs 4.4 months; hazard ratio $(\mathrm{HR})=0.3,95 \% \mathrm{CI}, 0.23$ to $0.41, \mathrm{p}<0.001$ ), and an ORR was significantly better with osimertinib ( $71 \%$ vs $31 \%$; odds ratio for objective response, 5.39; $95 \%$ CI, 3.47 to $8.48, \mathrm{p}<0.001)$. The results of this study lead to osimertinib's FDA approval in November 2015 for the treatment of patients with metastatic EGFR-m NSCLC with an acquired T790M mutation as detected by an FDAapproved test after tumor progression on an earlier generation EGFR-TKI. ${ }^{28}$

In the TREM study, the efficacy of osimertinib was assessed in both T790M-positive and T790M-negative patients. Patients with progression on at least one other EGFR-TKI were assigned to receive treatment with osimertinib $80 \mathrm{mg}$ once daily until radiologic progression or death with the primary endpoint being ORR. One hundred and ninety-nine patients were included with 120 (60\%) being $\mathrm{T} 790 \mathrm{M}$ positive. Of those that were
T790M positive, ORR was $60 \%(95 \% \mathrm{CI}, 51$ to $69 \%)$ and DoR was 11.8 months compared to $28 \%$ (95\% CI, 15 to $41 \%$ ) and 10.7 months for those that were T790Mnegative $(p=0.229)$. PFS was 10.8 months for T790M positive vs 5.1 months for T790M negative (HR 0.62, $\mathrm{p}=0.007$ ). OS was 22.5 months vs 13.4 months (HR 0.55, $\mathrm{p}=0.002$ ) for $\mathrm{T} 790 \mathrm{M}$ positive against negative. This study further emphasized osimertinib's role when treating patients positive for T790M NSCLC but also suggested that there is benefit from osimertinib in patients who had progressive cancers that were T790Mnegative. $^{38}$

\section{Osimertinib as Frontline Treatment for EGFR-Mutated NSCLC}

Given the promising results of the AURA3 trial, the FLAURA trial was conducted to investigate osimertinib's use in the front line setting of recurrent or metastatic EGFR-m, treatment naïve NSCLC. ${ }^{29}$ Patients enrolled into the study were randomly assigned in a $1: 1$ ratio to receive either osimertinib $80 \mathrm{mg}$ once daily or a firstgeneration EGFR-TKI (gefitinib $250 \mathrm{mg}$ daily or erlotinib $150 \mathrm{mg}$ daily). Patients with brain metastases were also included in this trial. The study met its primary endpoint of investigator-assessed PFS, which was reported as 18.9 months in the osimertinib arm compared to 10.2 months in the control (HR for disease progression or death $0.46,95 \%$ CI, 0.37 to 0.57 ; $<0.001)$. ORR was not different between the two groups, but duration of response was considerably longer in osimertinib arm at 17.2 months compared to 8.5 months on the first generation TKI arm. ${ }^{29}$ An updated 
follow up confirmed a benefit in OS with osimertinib as well, 38.6 months in the osimertinib arm vs 31.8 months in the other $\operatorname{arm} \quad(\mathrm{HR}=0.80 ; 95 \% \quad \mathrm{CI}, \quad 0.64$ to 1.00 ; $\mathrm{p}=0.046){ }^{39}$ This lead to the FDA granting osimertinib an approval in 2018 as first-line therapy for patients with metastatic NSCLC whose tumors have EGFR exon 19 deletion or exon 21 L858R mutation. ${ }^{33}$

\section{Osimertinib in Patients with Central Nervous System (CNS) Metastases}

Presence of CNS metastases is commonly observed in lung cancer patients with some studies reporting up to $65 \%$ lifetime incidence of brain metastases or leptomeningeal metastases (LMs) in patients with NSCLC. ${ }^{40} \mathrm{CNS}$ metastases are especially prevalent in patients with EGFRm lung cancer. ${ }^{41}$ TKIs have shown benefit in patients diagnosed with EGFR-m NSCLC and LMs, resulting in a median OS of 10 months versus 3.3 months in patients who did not receive TKIs. ${ }^{41}$ When it comes to earlier generation TKIs, their concentration within the cerebrospinal fluid is less than that found in the blood which in turn results in treatment failure due to pharmacokinetic limitations. $^{42}$ Osimertinib, on the other hand, effectively penetrates the blood-brain barrier, resulting in higher brain exposure than the previously tested EGFR-TKIs. A positron emission tomography (PET) study with radioisotope labeled osimertinib showed that the drug rapidly distributed within the brain, with a higher uptake into the grey compared to the white matter with a Tmax of 13 minutes (range 5-30min). ${ }^{43}$ In patients with CNS metastases evaluable-for-response, which was defined as one measurable CNS lesion in the AURA, AURA3 and FLAURA trials, collective CNS response rate was $71.6 \%$, control rate $93 \%$, and PFS 11.7 months. $^{28,44,45}$ A Phase 1 (BLOOM) study analyzed the activity of osimertinib in patients with EGFR-m NSCLC and LMs. Osimertinib was given at a dose of $160 \mathrm{mg}$ once daily until disease progression or there was unmanageable drugrelated toxicity. Within the trial, there was a total of 41 patients who were assessed for pre-defined endpoints of ORR, DoR, PFS, OS, pharmacokinetics (PK), and safety. Data from the trial showed an investigator assessed median duration of response (DoR) of 8.3 months (95\% CI, 5.6 to 16.5$)$, and an ORR of $41 \%(95 \% \mathrm{CI}, 26 \%$ to $58 \%)$ and neuroradiologic blinded committee review median DOR 15.2 months (95\% CI, 7.5 to 17.5$)$ and ORR of $62 \%(95 \%$
CI, $45 \%$ to $78 \%$ ), with adverse event rates similar to those found in previous osimertinib trials. ${ }^{46}$ The APOLLO study looked at the efficacy and safety of osimertinib for realworld patients with EGFR-T790M NSCLC and CNS metastases via circulating biomarkers for response to therapy. In the study, 38 patients were enrolled with a median follow-up of 8.2 months and demonstrated a median PFS of 8.4 months (95\% CI, 5.8 to 10.9) and ORR of $39.4 \%$ (95\% CI, 22.9 to 57.9$).{ }^{47}$ Multiple case reports have been published describing CNS efficacy of osimertinib. ${ }^{48}$

\section{Osimertinib as Adjuvant Therapy Post-Surgical Resection in Early Stage EGFR-m NSCLC}

Approximately $30 \%$ of patients with NSCLC present in early stage and are eligible to undergo curative surgical resection. Understandably, prognosis is highly dependent on stage at diagnosis with 5-year OS rate ranging from 60 to $74 \%$ for stage I, 47 to $55 \%$ for stage II, and $38 \%$ for stage IIIA. ${ }^{49}$ Although the use of chemotherapy in the adjuvant setting is the standard of care for stage II or III NSCLC, disease recurrence frequently occurs. An estimated $45 \%$ of patients diagnosed with stage IB, and $76 \%$ of patients diagnosed with stage III, succumb to disease recurrence despite adjuvant chemotherapy. ${ }^{50,51}$

The ADJUVANT/CTONG 1104 study investigated gefitinib's use in completely resected EGFR-m NSCLC. ${ }^{52}$ This was a phase 3 , open-label trial that randomized 222 patients in a 1:1 fashion to receive either gefitinib for two years or intravenous chemotherapy. Baseline demographics were similar amongst the two groups. Fifty-nine percent of patients in this study were female, three-quarter of patients were never smokers and $52 \%$ of patients had an exon 19 deletion. The primary endpoint was disease-free survival (DFS) and the median DFS was significantly longer with gefitinib compared to intravenous chemotherapy ([28.7 months 95\% CI, 24.9 to 32.5 ] vs 18.0 months [95\% CI, 13.6 to 22.3]; [HR=0.60, $95 \%$ CI 0.42 to $0.87 ; \mathrm{p}=0.0054])$. This ultimately did not translate to OS benefit (75.5 vs 62.8 months; $[\mathrm{HR}=0.92$; $95 \% \mathrm{CI}, 0.62$ to $1.36 ; \mathrm{p}=0.674]$ ) and recurrence in the CNS was common. ${ }^{53}$

The ADAURA study investigated osimertinib's use in resected $E G F R$-m NSCLC. This was a double-blind, phase 3 , randomized control trial, assigning patients in a $1: 1$ ratio to osimertinib $80 \mathrm{mg}$ once daily or placebo for 3 years with screening and randomization occurring after surgery. 
The primary endpoint of this study was DFS and OS was a secondary endpoint. At 24 months after randomization, $90 \%$ of the patients with stage II to IIIA disease in the osimertinib group (95\% CI, 84 to 93$)$ and $44 \%$ of those in the placebo group $(95 \% \mathrm{CI}, 37$ to 51$)$ were alive and disease-free (HR for disease recurrence or death, 0.17; $99.06 \% \mathrm{CI}, 0.11$ to 0.26 ; $\mathrm{p}<0.001$ ). The overall trial population had $89 \%$ of patients in the osimertinib group and $52 \%$ in the placebo group alive and disease-free at 24 months (HR for disease recurrence or death 0.20; $99.12 \%$ CI, 0.14 to $0.30 ; \mathrm{p}<0.001)$. Osimertinib's benefit was seen across all subgroups, but OS data has not yet matured. Recurrence of CNS related disease occurred in $2 \%$ and $11 \%$, respectively. Safety outcomes reported in the trial were similar to those found in other osimertinib trials with the most common adverse events being diarrhea, paronychia, and dry skin. ${ }^{50}$

\section{Efficacy of Osimertinib in NSCLC Harboring Relatively Less Common EGFR Mutations}

$E G F R$ exon 20 insertion mutation is the third most common type of $E G F R$ mutation after exon 19 deletions and L858R. EGFR-mutant tumors due to exon 20 insertions are observed in 4 to $10 \%$ of lung cancer diagnosis' and are commonly discovered in women, non-smokers, Asian populations with adenocarcinoma. ${ }^{10}$ Having EGFRmutant NSCLC due to exon 20 insertions differentiates from other $E G F R$ mutations due to an in-frame base pair insertion within exon 20, increasing resistance to firstand second-generation EGFR-TKIs, which yields very low response rates $(3-8 \%){ }^{10}$ This is because exon 20 insertions result in steric hindrance of the drug-binding pocket leading to increased ability of the receptor to bind ATP and decreased affinity to currently available EGFR$T K I{ }^{54}$ Preclinical studies suggested that osimertinib has activity against $E G F R$ exon 20 insertion mutations but in patients, responses are rare with standard $80 \mathrm{mg}$ dosing. ${ }^{55-57}$

The Phase 2 ECOG-ACRIN 5162 study analyzed osimertinib $160 \mathrm{mg}$ in advanced NSCLC patients with $E G F R$ exon 20 insertions in 20 patients. The ORR was $25 \%$, median PFS was 9.7 months (95\% CI, 4.07 to NA), and median DoR was 5.7 months (95\% CI, 4.73 to NA). The investigators of the study concluded that osimertinib $160 \mathrm{mg}$ is well-tolerated and that there is clinical benefit in this subset of patients warranting further studies. ${ }^{58}$
Other uncommon EGFR mutations consist of G719X, L861Q, S768I and L747S. An open-label phase 2 study investigated osimertinib's use in uncommon EGFR mutations, which included any EGFR mutation other than exon 19 deletion, L858R, T790M, or exon 20 insertion. ORR was $50 \%$ (95\% CI, 33\% to 67\%) and median PFS was 8.2 months $(95 \%$ CI, 5.9 to 10.5$)$ in all 36 patients. The most common mutation was G719X, which was present in 53\% of patients and an ORR of 53\% (95\% CI, 28\% to $77 \%$ ) was seen in these patients with a median PFS of 8.2 months (95\% CI, 6.2 to 10.2). L861Q was seen in $25 \%$ of patients with an ORR of $78 \%$ (95\% CI, 44\% to $100 \%$ and median PFS of 15.2 months (95\% CI, 1.3 to 29.1). S768I was seen in $22 \%$ of patients with an ORR of $38 \%$ (95\% CI, $0 \%$ to $81 \%$ and median PFS of 12.3 months (95\% CI, 0 to 28.8). ${ }^{59}$ Although data is still insufficient, this data demonstrates osimertinib as a potential option in patients with uncommon $E G F R$ mutations.

\section{Mechanisms of Resistance to Osimertinib}

Resistance to EGFR-TKI invariably occurs at some point during the disease course. For patients who progress on first and second generation TKI, development of secondary T790M mutation is the most commonly noted cause against, which osimertinib has excellent activity as detailed above. However, since osimertinib is now the preferred front-line agent for EGFRm NSCLC, new pathways for resistance are being unraveled. Common mechanisms discovered thus far include secondary resistance mechanisms that interact with osimertinib's binding to its primary site of action such as development of C797S mutation and activation of alternative signaling pathways independent of osimertinib's binding site. ${ }^{60}$ First and second-generation EGFR-TKIs are not affected by this mutation and second-line treatment with these medications are being analyzed to overcome this resistance. However, if the T790M mutation is present concurrently with the C797S mutation, a combination of osimertinib and an earlier generation EGFR-TKI is required to overcome both resistance mechanisms.

In the phase 1 AURA trial, there as a subpopulation of patients who clinically worsened while on osimertinib and the C797S mutation was present in $40 \%$ of these patients. $^{60}$ In the FLAURA study, mechanisms of resistance observed in patients that had disease progression while on osimertinib were: loss of T790M (68\%), EGFR 


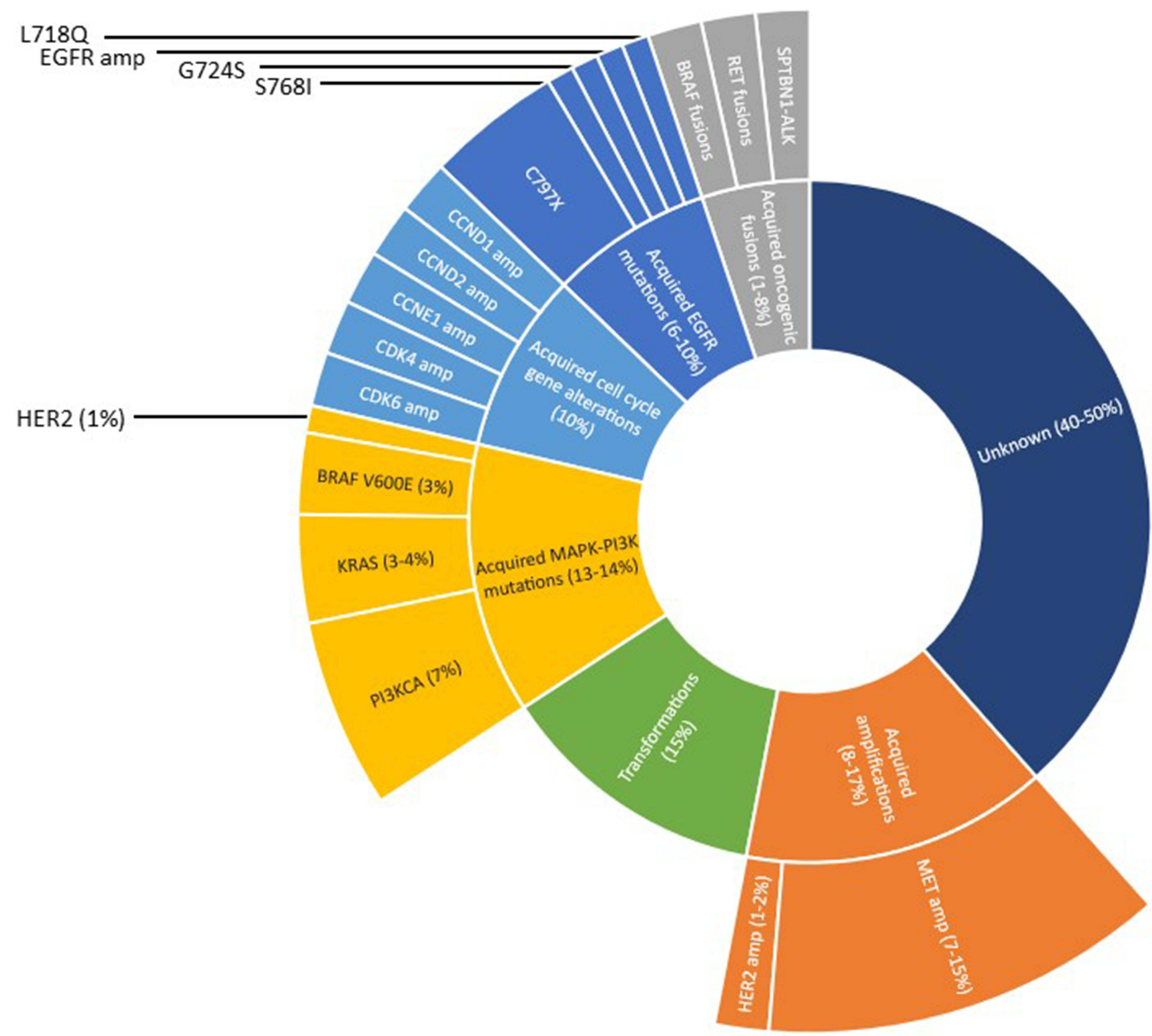

Figure I First line resistance to osimertinib; data from Leonetti et al. ${ }^{61}$

mutations (C797S, G724S, L718Q) (22\%), and in the other cases: MET amplifications, HER2 amplifications, PI3KCA mutations, KRAS or BRAF mutations, RET fusions, FGFR 3 fusions, and $B R A F$ fusions. ${ }^{60}$

Mutations within the L792, and L718 residues of $E G F R$ have also been discovered as resistance mechanisms to osimertinib. L792 mutations are not independent of other mutations and frequently coexist with other $E G F R$ mutations, occurring in cis with $7790 \mathrm{M}$ and in trans with G796/C797. ${ }^{61}$ Also responsible for resistance to osimertinib is within the $\mathrm{L} 718$ residue, most commonly being L718Q, which is located within the ATP-binding site of the EGFR kinase domain, altering the binding of osimertinib to EGFR. ${ }^{61}$ Figure 1 summarizes resistance mechanisms to osimertinib when used as first-line therapy. ${ }^{61}$

\section{Conclusion and Future Directions}

Osimertinib has demonstrated its superiority over first generation $E G F R$ TKIs with better PFS and OS in patients with EGFRm advanced or metastatic NSCLC. ${ }^{29,39}$ Recently, the ADAURA study demonstrated a $80 \%$ reduction in the risk of recurrence or death with osimertinib use in the adjuvant setting in patient with EGFRm NSCLC. ${ }^{50}$ With osimertinib commonly used as first line treatment for EGFRm advanced or metastatic NSCLC patients, the 
Table 2 Select Ongoing and Future Clinical Trials for Osimertinib

\begin{tabular}{|c|c|c|c|c|c|c|}
\hline Protocol Name & Phase & Patient Population & $\begin{array}{l}\text { Treatment } \\
\text { Regimen }\end{array}$ & $\begin{array}{l}\text { Target } \\
\text { Sample } \\
\text { Size (n) }\end{array}$ & $\begin{array}{l}\text { Primary } \\
\text { Outcomes }\end{array}$ & $\begin{array}{l}\text { Secondary } \\
\text { Outcomes }\end{array}$ \\
\hline $\begin{array}{l}\text { NCT044I320I } \\
\text { (AFAMOSI) }^{63}\end{array}$ & IV & $\begin{array}{l}\text { Treatment naïve EGFR mutated, T790M } \\
\text { negative, advanced or metastatic non- } \\
\text { squamous NSCLC }\end{array}$ & $\begin{array}{l}\text { Afatinib } \\
\text { followed by } \\
\text { osimertinib vs } \\
\text { osimertinib }\end{array}$ & 126 & $\begin{array}{l}\text { Time to } \\
\text { EGFR-TKI } \\
\text { failure at } 24 \\
\text { months }\end{array}$ & $\begin{array}{l}\text { PFS, OS, ORR, } \\
\text { DCR, safety, QOL }\end{array}$ \\
\hline NCT03535363 & 1 & $\begin{array}{l}\text { Treatment naïve EGFR mutated metastatic } \\
\text { NSCLC with BM }(1-10)\end{array}$ & $\begin{array}{l}\text { Osimertinib + } \\
\text { SRS }\end{array}$ & 40 & MTD & $\begin{array}{l}\text { PFS, OS, CNS } \\
\text { ORR, ORR }\end{array}$ \\
\hline NСT03667820 & ॥ & $\begin{array}{l}\text { Treatment naïve EGFR mutated metastatic } \\
\text { NSCLC }\end{array}$ & $\begin{array}{l}\text { Osimertinib + } \\
\text { SABR }\end{array}$ & 37 & PFS & $\begin{array}{l}\text { OS, DOR, ORR, } \\
\text { safety, time to } \\
\text { subsequent SABR }\end{array}$ \\
\hline NCT0439I28366 & IV & $\begin{array}{l}\text { Treatment naïve EGFR mutated metastatic } \\
\text { NSCLC }\end{array}$ & Osimertinib & 500 & TTD & $\begin{array}{l}\text { PFS, ORR, DCR, } \\
\text { OS, safety }\end{array}$ \\
\hline NCT04438902 $2^{67}$ & II & $\begin{array}{l}\text { Progression on osimertinib with EGFR } \\
\text { T790M mutated NSCLC }\end{array}$ & $\begin{array}{l}\text { Osimertinib + } \\
\text { anlotinib }\end{array}$ & 30 & PFS & ORR, DCR, safety \\
\hline $\begin{array}{l}\text { NCT03969823 } \\
\text { (WARRIOR) }^{68}\end{array}$ & II & $\begin{array}{l}\text { Treatment naïve EGFR mutated metastatic } \\
\text { NSCLC }\end{array}$ & Osimertinib & 148 & $\begin{array}{l}\text { Proportion } \\
\text { of acquired } \\
\text { resistance } \\
\text { mechanisms }\end{array}$ & $\begin{array}{l}\text { Safety, PFS, OS, } \\
\text { ORR }\end{array}$ \\
\hline $\begin{array}{l}\text { NCT0456387I } \\
\left(^{B L O S S O M}\right)^{69}\end{array}$ & II & $\begin{array}{l}\text { Progression on EGFR TKI with LM with } \\
\text { EGFR mutated NSCLC }\end{array}$ & Osimertinib & 80 & OS & $\begin{array}{l}\text { LM ORR, LM } \\
\text { DOR, LM DCR, } \\
\text { LM PFS }\end{array}$ \\
\hline $\begin{array}{l}\text { NCT03497767 } \\
(\text { OUTRUN) })^{70}\end{array}$ & II & $\begin{array}{l}\text { Treatment naïve EGFR mutated metastatic } \\
\text { NSCLC with BM }\end{array}$ & $\begin{array}{l}\text { Osimertinib + } \\
\text { SRS }\end{array}$ & 80 & IC PFS & $\begin{array}{l}\text { Use of WBRT, } \\
\text { brain failure, OS }\end{array}$ \\
\hline NСT03 $122717^{71}$ & $1 / I I$ & $\begin{array}{l}\text { Treatment naïve EGFR mutated locally } \\
\text { advanced or metastatic NSCLC }\end{array}$ & $\begin{array}{l}\text { Osimertinib + } \\
\text { gefitinib }\end{array}$ & 64 & Safety & ORR, PFS, OS \\
\hline 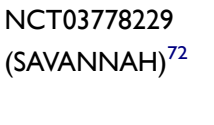 & II & $\begin{array}{l}\text { Progression on osimertinib with EGFR } \\
\text { mutated and MET mutated locally advanced } \\
\text { or metastatic NSCLC }\end{array}$ & $\begin{array}{l}\text { Osimertinib + } \\
\text { savolitinib }\end{array}$ & 259 & ORR & $\begin{array}{l}\text { PFS, OS, DOR, } \\
\text { QOL, safety }\end{array}$ \\
\hline NCT03543683 & IV & $\begin{array}{l}\text { Progression on first generation EGFR TKI } \\
\text { with T790M mutated NSCLC }\end{array}$ & $\begin{array}{l}\text { Osimertinib + } \\
\text { aspirin }\end{array}$ & 330 & PFS & OS \\
\hline $\begin{array}{l}\text { NCT0385849I } \\
\text { (OSIBOOST) }^{74}\end{array}$ & I & $\begin{array}{l}\text { Treatment naïve EGFR mutated metastatic } \\
\text { NSCLC }\end{array}$ & $\begin{array}{l}\text { Osimertinib + } \\
\text { cobicistat }\end{array}$ & 26 & $\begin{array}{l}\text { Osimertinib } \\
\text { AUC }\end{array}$ & Safety \\
\hline $\begin{array}{l}\text { NCT03940703 } \\
\text { (INSIGHT } 2 \\
\text { Study }^{75}\end{array}$ & II & $\begin{array}{l}\text { MET Amplified, EGFR mutated advanced or } \\
\text { metastatic NSCLC having acquired } \\
\text { resistance to prior EGFR TKI }\end{array}$ & $\begin{array}{l}\text { Tepotinib + } \\
\text { osimertinib }\end{array}$ & 120 & Safety, ORR & $\begin{array}{l}\text { DOR, DCR, PFS, } \\
\text { OS, QOL }\end{array}$ \\
\hline $\begin{array}{l}\text { NCT04035486 } \\
(\text { FLAURA2) }\end{array}$ & III & $\begin{array}{l}\text { Treatment naïve EGFR mutated locally } \\
\text { advanced or metastatic NSCLC }\end{array}$ & $\begin{array}{l}\text { Osimertinib + } \\
\text { pemetrexed + } \\
\text { cisplatin or } \\
\text { carboplatin }\end{array}$ & 586 & PFS & $\begin{array}{l}\text { OS, ORR, DOR, } \\
\text { DCR }\end{array}$ \\
\hline NCT03392246 & ॥ & $\begin{array}{l}\text { Treatment naïve EGFR mutated locally } \\
\text { advanced or metastatic NSCLC }\end{array}$ & $\begin{array}{l}\text { Osimertinib + } \\
\text { selumetinib }\end{array}$ & 25 & Best OR & PFS, OS, safety \\
\hline
\end{tabular}


Table 2 (Continued).

\begin{tabular}{|c|c|c|c|c|c|c|}
\hline Protocol Name & Phase & Patient Population & $\begin{array}{l}\text { Treatment } \\
\text { Regimen }\end{array}$ & $\begin{array}{l}\text { Target } \\
\text { Sample } \\
\text { Size (n) }\end{array}$ & $\begin{array}{l}\text { Primary } \\
\text { Outcomes }\end{array}$ & $\begin{array}{l}\text { Secondary } \\
\text { Outcomes }\end{array}$ \\
\hline NCT03891615 & 1 & $\begin{array}{l}\text { Progression on osimertinib with EGFR } \\
\text { mutated metastatic NSCLC }\end{array}$ & $\begin{array}{l}\text { Osimertinib + } \\
\text { niraparib }\end{array}$ & 30 & MTD & Toxicity, ORR, PFS \\
\hline NCT04I8492। $I^{79}$ & IV & $\begin{array}{l}\text { Progression on osimertinib with EGFR } \\
\text { mutated metastatic NSCLC }\end{array}$ & $\begin{array}{l}\text { Osimertinib + } \\
\text { aspirin }\end{array}$ & 350 & PFS & OS, ORR, TTP \\
\hline NCT03532698 & III & $\begin{array}{l}\text { Progression on osimertinib with EGFR } \\
\text { T790M mutated metastatic NSCLC }\end{array}$ & $\begin{array}{l}\text { Osimertinib + } \\
\text { aspirin }\end{array}$ & 100 & ORR & DCR, TTP, DOR \\
\hline $\begin{array}{l}\text { NCT0423302I } \\
(\text { ORBITAL) })^{81}\end{array}$ & II & $\begin{array}{l}\text { EGFR mutated metastatic NSCLC with BM } \\
\text { or LM }\end{array}$ & Osimertinib & 113 & ORR & $\begin{array}{l}\text { OS, PFS, safety, } \\
\text { QOL }\end{array}$ \\
\hline NCT03769103 $3^{82}$ & II & $\begin{array}{l}\text { Treatment naïve EGFR mutated metastatic } \\
\text { NSCLC with BM }\end{array}$ & $\begin{array}{l}\text { Osimertinib + } \\
\text { SRS }\end{array}$ & 76 & IC PFS & $\begin{array}{l}\text { IC ORR, time to } \\
\text { WBRT, OS, QOL }\end{array}$ \\
\hline NCT04591002 ${ }^{83}$ & II & $\begin{array}{l}\text { Progression of remaining GGN after } \\
\text { curative resection for EGFR mutated stage } \\
\text { I adenocarcinoma }\end{array}$ & $\begin{array}{l}\text { Osimertinib } \\
\text { (adjuvant) }\end{array}$ & 56 & $\begin{array}{l}\text { Regression } \\
\text { rate }\end{array}$ & $\begin{array}{l}\text { Avoidance of } \\
\text { subsequent } \\
\text { treatments, rate of } \\
\text { treatment failure, } \\
\text { safety }\end{array}$ \\
\hline NCT03909334 $4^{84}$ & II & $\begin{array}{l}\text { Treatment naïe EGFR mutated locally } \\
\text { advanced or metastatic NSCLC }\end{array}$ & $\begin{array}{l}\text { Osimertinib + } \\
\text { ramucirumab }\end{array}$ & 150 & PFS & $\begin{array}{l}\text { ORR, DCR, OS, } \\
\text { safety }\end{array}$ \\
\hline NCT0400I777 85 & I & EGFR mutated metastatic NSCLC & $\begin{array}{l}\text { APG-I252 + } \\
\text { osimertinib }\end{array}$ & 60 & MTD, RP2D & Efficacy \\
\hline NCT03810807 86 & I & $\begin{array}{l}\text { Treatment naïve EGFR mutated metastatic } \\
\text { NSCLC }\end{array}$ & $\begin{array}{l}\text { Dacomitinib + } \\
\text { osimertinib }\end{array}$ & 22 & $\begin{array}{l}\text { MTD, best } \\
\text { ORR }\end{array}$ & N/A \\
\hline NCT03255083 ${ }^{87}$ & I & $\begin{array}{l}\text { Progression on EGFR TKI with EGFR } \\
\text { mutated locally advanced or metastatic } \\
\text { NSCLC }\end{array}$ & $\begin{array}{l}\text { DS-1205c + } \\
\text { osimertinib }\end{array}$ & 13 & Safety & $\begin{array}{l}\text { PD, PK, ORR, } \\
\text { DCR, PFS, OS }\end{array}$ \\
\hline NCT04486833 & $\mathrm{I} / \mathrm{II}$ & $\begin{array}{l}\text { Progression on osimertinib with EGFR } \\
\text { mutated locally advanced or metastatic } \\
\text { NSCLC }\end{array}$ & $\begin{array}{l}\text { Quaratusugene } \\
\text { ozeplasmid } \\
(\text { GPX-00I) }+ \\
\text { osimertinib }\end{array}$ & 100 & MTD, PFS2 & $\begin{array}{l}\text { ORR, OS, DOT, } \\
\text { safety }\end{array}$ \\
\hline NCT034344I8 $8^{89}$ & II & $\begin{array}{l}\text { Treatment naïe uncommon EGFR mutated } \\
\text { locally advanced or metastatic NSCLC } \\
\text { (exon I8 G7I9X, exon } 20 \text { S768l, or exon } \\
2 \text { I L86IQ) }\end{array}$ & Osimertinib & 37 & ORR & PFS, safety, OS \\
\hline NCT02803203 90 & $\mathrm{I} / \mathrm{II}$ & $\begin{array}{l}\text { Treatment naive EGFR mutated metastatic } \\
\text { NSCLC }\end{array}$ & $\begin{array}{l}\text { Bevacizumab + } \\
\text { osimertinib }\end{array}$ & 50 & MTD, PFS & $N / A$ \\
\hline $\begin{array}{l}\text { NCT0352। I54 } \\
(\text { LAURA })^{91}\end{array}$ & III & $\begin{array}{l}\text { EGFR mutated stage III unresectable } \\
\text { NSCLC }\end{array}$ & $\begin{array}{l}\text { Osimertinib } \\
\text { following } \\
\text { chemoradiation }\end{array}$ & 200 & PFS & $\begin{array}{l}\text { CNS PFS, OS, } \\
\text { ORR, DOR, DCR, } \\
\text { safety }\end{array}$ \\
\hline NCT0343346992 & $\|$ & $\begin{array}{l}\text { Surgically resectable, EGFR mutated Stage } \\
\text { I-IIIA NSCLC }\end{array}$ & $\begin{array}{l}\text { Osimertinib } \\
\text { (neoadjuvant) }\end{array}$ & 27 & MPR & $\begin{array}{l}\text { ORR, DFS, OS, } \\
\text { DOR, safety }\end{array}$ \\
\hline
\end{tabular}

(Continued) 
Table 2 (Continued).

\begin{tabular}{|c|c|c|c|c|c|c|}
\hline Protocol Name & Phase & Patient Population & $\begin{array}{l}\text { Treatment } \\
\text { Regimen }\end{array}$ & $\begin{array}{l}\text { Target } \\
\text { Sample } \\
\text { Size (n) }\end{array}$ & $\begin{array}{l}\text { Primary } \\
\text { Outcomes }\end{array}$ & $\begin{array}{l}\text { Secondary } \\
\text { Outcomes }\end{array}$ \\
\hline NCT03989II $5^{93}$ & $\mathrm{I} / \mathrm{II}$ & $\begin{array}{l}\text { Progression on osimertinib with EGFR } \\
\text { mutated locally advanced or metastatic } \\
\text { NSCLC }\end{array}$ & $\begin{array}{l}\text { RMC-4630 + } \\
\text { osimertinib }\end{array}$ & 168 & Safety, DLT & PK, ORR, DOR \\
\hline 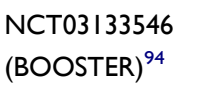 & ॥ & $\begin{array}{l}\text { Progression on first generation EGFR TKI } \\
\text { with T790M mutated NSCLC }\end{array}$ & $\begin{array}{l}\text { Bevacizumab + } \\
\text { osimertinib }\end{array}$ & 155 & PFS & ORR, OS, safety \\
\hline NCT04085315 $5^{95}$ & 1 & $\begin{array}{l}\text { Progression on osimertinib with EGFR } \\
\text { mutated metastatic NSCLC }\end{array}$ & $\begin{array}{l}\text { Alisertib + } \\
\text { osimertinib }\end{array}$ & 36 & Safety & $\begin{array}{l}\text { ORR, DOR, DCR, } \\
\text { PFS, OS, CNS } \\
\text { DCR }\end{array}$ \\
\hline NCT034I $4814^{96}$ & ॥ & $\begin{array}{l}\text { Progression on chemotherapy with EGFR } \\
\text { Exon } 20 \text { mutation locally advanced or } \\
\text { metastatic NSCLC }\end{array}$ & Osimertinib & 28 & ORR & $\begin{array}{l}\text { Safety, PFS, OS, } \\
\text { DOR }\end{array}$ \\
\hline $\begin{array}{l}\text { NCT0435I555 } \\
(\text { NeoADAURA })^{97}\end{array}$ & III & EGFR mutated resectable NSCLC & $\begin{array}{l}\text { Osimertinib + } \\
\text { pemetrexed + } \\
\text { cisplatin or } \\
\text { carboplatin }\end{array}$ & 328 & MPR & $\begin{array}{l}\text { PCR, EFS, OS, DFS, } \\
\text { QOL }\end{array}$ \\
\hline NCT0356764298 & I & $\begin{array}{l}\text { Treatment naïve EGFR mutated metastatic } \\
\text { NSCLC with concurrent RBI and TP53 } \\
\text { alterations }\end{array}$ & $\begin{array}{l}\text { Osimertinib + } \\
\text { platinum } \\
\text { chemotherapy } \\
+ \text { etoposide }\end{array}$ & 20 & MTD & $\mathrm{N} / \mathrm{A}$ \\
\hline NCT0447930699 & 1 & $\begin{array}{l}\text { Progression on osimertinib with EGFR } \\
\text { mutated locally advanced or metastatic } \\
\text { NSCLC }\end{array}$ & $\begin{array}{l}\text { Osimertinib + } \\
\text { alisertib or } \\
\text { sapanisertib }\end{array}$ & 40 & $\begin{array}{l}\text { DLT, RP2D, } \\
\text { safety }\end{array}$ & ORR, PFS \\
\hline NCT02496663 100 & I & $\begin{array}{l}\text { Progression on EGFR TKI with EGFR } \\
\text { mutated locally advanced or metastatic } \\
\text { NSCLC }\end{array}$ & $\begin{array}{l}\text { Osimertinib + } \\
\text { necitumumab }\end{array}$ & 100 & MTD, safety & $\begin{array}{l}\text { ORR, PFS, DCR, } \\
\text { PK }\end{array}$ \\
\hline NCT03831932 101 & I & $\begin{array}{l}\text { Progression on EGFR TKI with EGFR } \\
\text { mutated locally advanced or metastatic } \\
\text { NSCLC }\end{array}$ & $\begin{array}{l}\text { Telaglenastat }+ \\
\text { osimertinib }\end{array}$ & 18 & RP2D & DLT, PFS, OS \\
\hline NCT02954523 ${ }^{102}$ & $\mathrm{I} / \mathrm{II}$ & $\begin{array}{l}\text { Treatment naïve EGFR mutated locally } \\
\text { advanced or metastatic NSCLC }\end{array}$ & $\begin{array}{l}\text { Osimertinib + } \\
\text { dasatinib }\end{array}$ & 10 & Safety & $\begin{array}{l}\text { PK, PD, PFS, OS, } \\
\text { DOR }\end{array}$ \\
\hline $\begin{array}{l}\text { NCT0442568I } \\
(\text { OWBLM) }\end{array}$ & ॥ & $\begin{array}{l}\text { EGFR mutated advanced or metastatic } \\
\text { NSCLC with leptomeningeal metastasis }\end{array}$ & $\begin{array}{l}\text { Osimertinib + } \\
\text { bevacizumab }\end{array}$ & 20 & $\begin{array}{l}\text { CNS PFS, } \\
\text { ORR }\end{array}$ & $\begin{array}{l}\text { CNS OS, PFS, } \\
\text { safety }\end{array}$ \\
\hline NCT04I $48898^{104}$ & II & $\begin{array}{l}\text { EGFR mutated advanced or metastatic } \\
\text { NSCLC with leptomeningeal metastasis }\end{array}$ & $\begin{array}{l}\text { Osimertinib + } \\
\text { bevacizumab }\end{array}$ & 80 & $\begin{array}{l}\text { CNS PFS, } \\
\text { ORR }\end{array}$ & $\begin{array}{l}\text { CNS OS, PFS, } \\
\text { safety }\end{array}$ \\
\hline NCT02736513 105 & II & $\begin{array}{l}\text { Treatment naïve or previously treated } \\
\text { advanced EGFR mutated metastatic NSCLC } \\
\text { with asymptomatic BM }\end{array}$ & Osimertinib & 40 & IC ORR & $\begin{array}{l}\text { IC DCR, time to } \\
\text { IC response, IC } \\
\text { PFS }\end{array}$ \\
\hline NCT0460677। 106 & II & $\begin{array}{l}\text { Progression on osimertinib with EGFR } \\
\text { mutated and MET amplified advanced } \\
\text { NSCLC }\end{array}$ & $\begin{array}{l}\text { Savolitinib + } \\
\text { osimertinib }\end{array}$ & 56 & ORR & $\begin{array}{l}\text { PFS, DOR, TSA, } \\
\text { OS, PK }\end{array}$ \\
\hline
\end{tabular}

(Continued) 
Table 2 (Continued).

\begin{tabular}{|c|c|c|c|c|c|c|}
\hline Protocol Name & Phase & Patient Population & $\begin{array}{l}\text { Treatment } \\
\text { Regimen }\end{array}$ & $\begin{array}{l}\text { Target } \\
\text { Sample } \\
\text { Size (n) }\end{array}$ & $\begin{array}{l}\text { Primary } \\
\text { Outcomes }\end{array}$ & $\begin{array}{l}\text { Secondary } \\
\text { Outcomes }\end{array}$ \\
\hline NCT044I0796 107 & $\|$ & $\begin{array}{l}\text { Treatment naive EGFR mutated (cfDNA in } \\
\text { plasma) locally advanced or metastatic } \\
\text { NSCLC }\end{array}$ & $\begin{array}{l}\text { Osimertinib + } \\
\text { carboplatin }+ \\
\text { pemetrexed }\end{array}$ & 571 & PFS & ORR \\
\hline NCT04I4I644 & IB & $\begin{array}{l}\text { EGFR mutated locally advanced or } \\
\text { metastatic NSCLC stable on osimertinib }\end{array}$ & $\begin{array}{l}\text { Osimertinib + } \\
\text { ipilimumab }\end{array}$ & 26 & Safety & ORR, PFS, OS \\
\hline NCT04181060109 & III & $\begin{array}{l}\text { Treatment naïve EGFR mutated locally } \\
\text { advanced or metastatic NSCLC }\end{array}$ & $\begin{array}{l}\text { Osimertinib + } \\
\text { bevacizumab }\end{array}$ & 300 & PFS & $\begin{array}{l}\text { OS, best ORR, } \\
\text { CNS PFS, safety }\end{array}$ \\
\hline NCT034558291/0 & $\mid \mathrm{IB} / \mathrm{II}$ & $\begin{array}{l}\text { Treatment naive EGFR mutated metastatic } \\
\text { NSCLC }\end{array}$ & $\begin{array}{l}\text { Lerociclib + } \\
\text { osimertinib }\end{array}$ & 30 & $\begin{array}{l}\text { DLT, RP2D, } \\
\text { safety, PFS }\end{array}$ & ORR, PK, OS \\
\hline $\begin{array}{l}\text { NCT04335292 } \\
(\text { OCELOT) })^{111}\end{array}$ & II & $\begin{array}{l}\text { Previously treated with osimertinib } \\
\text { and second line platinum and pemetrexed }\end{array}$ & Osimertinib & 200 & ORR & $\begin{array}{l}\text { PFS, DOR, DCR, } \\
\text { OS, TTF, QOL }\end{array}$ \\
\hline NCT02503722 112 & I & $\begin{array}{l}\text { Progression on osimertinib with EGFR } \\
\text { mutated advanced or metastatic NSCLC }\end{array}$ & $\begin{array}{l}\text { Sapanisertib + } \\
\text { osimertinib }\end{array}$ & 36 & Safety & $\begin{array}{l}\text { PK, PD, ORR, } \\
\text { DCR, PFS }\end{array}$ \\
\hline NCT04545710 113 & ॥ & $\begin{array}{l}\text { Progression on osimertinib with EGFR } \\
\text { mutated advanced or metastatic NSCLC }\end{array}$ & $\begin{array}{l}\text { Osimertinib + } \\
\text { abemaciclib }\end{array}$ & 18 & PFS & $N / A$ \\
\hline NCT02520778 114 & I & $\begin{array}{l}\text { Progression on EGFR TKI with EGFR } \\
\text { mutated locally advanced or metastatic } \\
\text { NSCLC }\end{array}$ & $\begin{array}{l}\text { Osimertinib + } \\
\text { navitoclax }\end{array}$ & 50 & Safety & PK, ORR, \\
\hline NCT02824952 115 & ॥ & $\begin{array}{l}\text { Treatment naïve stage IIIA/B EGFR mutated } \\
\text { NSCLC }\end{array}$ & $\begin{array}{l}\text { Osimertinib } \\
\text { (neoadjuvant) }\end{array}$ & 40 & ORR & PFS, tumor volume \\
\hline NCT02917993 116 & $1 / I I$ & $\begin{array}{l}\text { Progression on EGFR TKI with EGFR } \\
\text { mutated locally advanced or metastatic } \\
\text { NSCLC }\end{array}$ & $\begin{array}{l}\text { Itacitinib + } \\
\text { osimertinib }\end{array}$ & 59 & $\begin{array}{l}\text { Safety, DLT, } \\
\text { ORR }\end{array}$ & PK, PFS, OS \\
\hline NCT04029350 117 & ॥ & $\begin{array}{l}\text { Progression on EGFR TKI with EGFR and } \\
\text { T790M mutation locally advanced or } \\
\text { metastatic NSCLC }\end{array}$ & $\begin{array}{l}\text { Anlotinib + } \\
\text { osimertinib }\end{array}$ & 53 & PFS & $\begin{array}{l}\text { OS, ORR, DCR, } \\
\text { safety }\end{array}$ \\
\hline NCT02789345 118 & I & $\begin{array}{l}\text { Progression on EGFR TKI with EGFR } \\
\text { T790M mutated advanced NSCLC }\end{array}$ & $\begin{array}{l}\text { Osimertinib + } \\
\text { ramucirumab } \\
\text { or } \\
\text { necitumumab }\end{array}$ & 74 & Safety & $\begin{array}{l}\text { PK, PD, ORR, } \\
\text { DCR, DOR, PFS, } \\
\text { OS }\end{array}$ \\
\hline $\begin{array}{l}\text { NCT03784599 } \\
\left(\text { TRAEMOS) }^{119}\right.\end{array}$ & ॥ & $\begin{array}{l}\text { Progression on EGFR TKI with EGFR and } \\
\text { HER2 mutation locally advanced or } \\
\text { metastatic NSCLC }\end{array}$ & $\begin{array}{l}\text { Trastuzumab- } \\
\text { emtansine }+ \\
\text { osimertinib }\end{array}$ & 58 & Safety, ORR & PFS, DCR, OS \\
\hline NCT0297I50। 120 & $\|$ & $\begin{array}{l}\text { Treatment naïve EGFR mutated metastatic } \\
\text { NSCLC with BMs }\end{array}$ & $\begin{array}{l}\text { Osimertinib + } \\
\text { bevacizumab }\end{array}$ & 112 & PFS & $\begin{array}{l}\text { OS, safety, ORR, } \\
\text { IC ORR, }\end{array}$ \\
\hline $\begin{array}{l}\text { NCT034I0043 } \\
\text { (NORTHSTAR) }^{121}\end{array}$ & II & $\begin{array}{l}\text { EGFR mutated locally advanced or } \\
\text { metastatic NSCLC }\end{array}$ & $\begin{array}{l}\text { Osimertinib + } \\
\text { LCT }\end{array}$ & 143 & PFS & OS, safety \\
\hline NCT0428567| 122 & $\mathrm{I} / \mathrm{II}$ & $\begin{array}{l}\text { Progression on osimertinib with EGFR } \\
\text { mutated advanced or metastatic NSCLC }\end{array}$ & $\begin{array}{l}\text { Necitumumab } \\
+ \text { trastuzumab } \\
+ \text { osimertinib }\end{array}$ & 26 & $\begin{array}{l}\text { R2PD, safety, } \\
\text { ORR }\end{array}$ & $\begin{array}{l}\text { PFS, DOR, OS } \\
\text { QOL }\end{array}$ \\
\hline
\end{tabular}

(Continued) 
Table 2 (Continued).

\begin{tabular}{|c|c|c|c|c|c|c|}
\hline Protocol Name & Phase & Patient Population & $\begin{array}{l}\text { Treatment } \\
\text { Regimen }\end{array}$ & $\begin{array}{l}\text { Target } \\
\text { Sample } \\
\text { Size (n) }\end{array}$ & $\begin{array}{l}\text { Primary } \\
\text { Outcomes }\end{array}$ & $\begin{array}{l}\text { Secondary } \\
\text { Outcomes }\end{array}$ \\
\hline $\begin{array}{l}\text { NCT04487080 } \\
\text { (MARIPOSA) }^{123}\end{array}$ & III & $\begin{array}{l}\text { Treatment naïve EGFR mutated locally } \\
\text { advanced or metastatic NSCLC }\end{array}$ & $\begin{array}{l}\text { Amivantamab + } \\
\text { lazertinib vs } \\
\text { lazertinib }\end{array}$ & 1000 & PFS & $\begin{array}{l}\text { OS, ORR, DOR, IC } \\
\text { PFS, safety }\end{array}$ \\
\hline NCT04338243 124 & $\mid / I I$ & $\begin{array}{l}\text { Progression on EGFR TKI with EGFR } \\
\text { mutated advanced NSCLC }\end{array}$ & $\begin{array}{l}\text { Glumetinib + } \\
\text { osimertinib }\end{array}$ & 70 & ORR & DOR, OS \\
\hline NСT03755102 125 & I & $\begin{array}{l}\text { Progression on osimertinib with EGFR } \\
\text { mutated advanced or metastatic NSCLC }\end{array}$ & $\begin{array}{l}\text { Dacomitinib + } \\
\text { osimertinib }\end{array}$ & 24 & ORR & PFS, OS \\
\hline NСT03807778 126 & $\mathrm{I} / \mathrm{II}$ & $\begin{array}{l}\text { EGFR mutated, exon } 20 \text { locally advanced or } \\
\text { metastatic NSCLC who have progressed on } \\
\text { EGFR-TKI }\end{array}$ & Osimertinib & 63 & Safety & $\begin{array}{l}\text { PK, PD, ORR, } \\
\text { DOR, DCR, PFS, } \\
\text { OS, QOL }\end{array}$ \\
\hline NСT03769103 127 & $\|$ & $\begin{array}{l}\text { Treatment naïve EGFR mutated metastatic } \\
\text { NSCLC with BM }\end{array}$ & $\begin{array}{l}\text { Osimertinib + } \\
\text { SRS }\end{array}$ & 76 & CNS PFS & $\begin{array}{l}\text { CNS OS, time to } \\
\text { SRS/WBRT, OS, } \\
\text { QOL }\end{array}$ \\
\hline NCT04I29502 128 & III & $\begin{array}{l}\text { Treatment naïve EGFR mutated, exon } 20 \\
\text { locally advanced or metastatic NSCLC }\end{array}$ & Osimertinib & 318 & PFS & $\begin{array}{l}\text { ORR, OS, DOR, } \\
\text { DCR, QOL }\end{array}$ \\
\hline NСT02716116 $6^{129}$ & $1 / I I$ & $\begin{array}{l}\text { EGFR/HER2 mutated locally advanced or } \\
\text { metastatic NSCLC (also includes exon 20) }\end{array}$ & Osimertinib & 306 & ORR & $\begin{array}{l}\text { PK, PD, DOR, } \\
\text { DCR, PFS, OS }\end{array}$ \\
\hline NСT03755102 130 & I & $\begin{array}{l}\text { Progression on osimertinib with EGFR } \\
\text { mutated advanced or metastatic NSCLC }\end{array}$ & $\begin{array}{l}\text { Dacomitinib + } \\
\text { osimertinib }\end{array}$ & 24 & ORR & PFS, OS \\
\hline
\end{tabular}

Abbreviations: BM, brain metastases; CNS, central nervous system; DCR, disease control rate; DFS, disease free survival; DOR, duration of response; EGFR, epidermal growth factor receptor; EFS, event-free survival; GGN, ground-glass opacity nodule; IC, intracranial; LCT, local consolidation therapy; LM, leptomeningeal metastases; MET, mesenchymal-epithelial transition factor; MPR, major pathological response; MTD, maximum tolerated dose; NSCLC, non-small cell lung cancer; ORR, objective response rate; OS, overall survival; PCR, pathological complete response; PD, pharmacodynamics; PK, pharmacokinetics; PFS, progression-free survival; QOL, quality of life; RP2D, recommended phase 2 dose; SABR, stereotactic ablative radiation; SRS, stereotactic radiosurgery; TKI, tyrosine kinase inhibitor; TSA, tumor size assessment; TTP, time to progression; TTD, time to discontinuation; TTF, time to treatment Failure; WBRT, whole brain radiotherapy.

clinical question of how to overcome disease progression while on osimertinib comes in to play. One of the more paramount clinical scenarios being studied is how to properly overcome acquired resistance to osimertinib. The specific configuration of T790M and C797S in the trans position is resistant to third-generation EGFR-TKIs, but is sensitive to a combination therapy with third-generation EGFR-TKIs. ${ }^{62}$ To help overcome acquired resistance to osimertinib, combination therapies are being studied to give patients another option if treatment failure with osimertinib develops. Table 2 summarizes the many ongoing clinical trials with osimertinib including combination therapy with anlotinib, savolitinib, aspirin, cobicistat, tepotinib, niraparib, quaratusugene ozeplasmid, alisertib, sapanisertib, necitumumab, telaglenastat, sapanisertib, abemaciclib and itacitinib. ${ }^{63-130}$

Osimertinib's benefit against chemotherapy was proven in the AURA3 study with a better overall ORR than the platinum-pemetrexed combination. ${ }^{28}$ Currently being studied is the combination of osimertinib with carboplatin and pemetrexed in individuals diagnosed with metastatic lung cancer with an EGFR mutation. ${ }^{76,111}$ Hypothesized with this combination therapy is the ability to help further suppress cancer progression in these patients and limit the development of resistance. A phase 2, open-label, randomized study is underway analyzing osimertinib alone vs combination with pemetrexed and carboplatin in patients with detectable EGFRm cfDNA after being already started on osimertinib. Patients will be receiving either osimertinib $80 \mathrm{mg}$ daily or osimertinib $80 \mathrm{mg}$ daily with carboplatin AUC of 5 IV every 3 weeks and pemetrexed $500 \mathrm{mg} / \mathrm{m}^{2}$ IV every 3 weeks for a total of 4 cycles. Primary outcome of this study is assessing PFS from the duration of time when randomization was conducted to when disease progression was observed. A secondary endpoint will be intracranial PFS, analyzing from time of randomization to disease progression within the CNS or death. ${ }^{107}$ 
MET driven acquired resistance is becoming more prevalent in patients diagnosed with NSCLC. Preclinical data have analyzed osimertinib's role in combination with a MET TKI for treatment of EGFR mutation-positive lung cancer with $M E T$ acquired resistance. In a multicenter, phase $1 \mathrm{~b}$ study, patients were enrolled with locally advanced or metastatic, MET-amplified, EGFR mutation-positive NSCLC who had disease progression on EGFR-TKIs. Patients received osimertinib $80 \mathrm{mg}$ and savolitinib (MET inhibitor) $600 \mathrm{mg}$ daily (patients weighing more than $55 \mathrm{~kg}$ received $300 \mathrm{mg}$ of savolitinib). Among 69 patients within the study that had previous third-generation EGFR-TKI exposure, ORR was $30 \%$ Safety profile observed were adverse events of grade $>/=3$ occurring in $57 \%$ of patients with most common being increases in aspartate aminotransferase, and neutropenia. Investigators concluded that this combination is associated with an acceptable risk-benefit profile and encouraging antitumor activity with $M E T$-amplified, EGFR mutation-positive, advanced NSCLC for patients who had disease progression on a previous EGFR-TKI. ${ }^{131}$ The combination of osimertinib and tepotinib, another MET inhibitor is currently being investigated in the INSIGHT 2 trial. $^{75}$

Another therapeutic combination being studied is osimertinib and bevacizumab in patients with CNS metastases (specifically LMs). Bevacizumab is a recombinant humanized monoclonal antibody against $V E G F$, where in animal studies, plays a key role in LMs. Theorized is that inhibition of both EGFR and $V E G R$ signaling pathways could enhance the antitumor efficacy and further prevent resistance to EGFR-TKIs. Recently in a phase 2 study, the addition of bevacizumab to osimertinib was not shown to be beneficial in previously treated EGFR TKIs patients with the T790M mutation. ${ }^{132}$

Osimertinib provides substantial benefit for a robust patient population suffering from a diagnosis with NSCLC. Its unique receptor binding properties are novel within the EGFR-TKI class. As study results progress further and expand osimertinib's use across different clinical settings, it is of importance to keep the clinical benefit relevant and not allow further resistance mechanisms to develop.

\section{Disclosure}

Dr Chung-Shien Lee is an Advisory Board participant for G1 Therapeutics. Nagashree Seetharamu has served on the advisory boards for Genentech, Amgen, Takeda and AstraZeneca in the last year. The authors report no other conflicts of interest in this work.

\section{References}

1. Collins LG, Haines C, Perkel R, Enck RE. Lung cancer: diagnosis and management; 2007. Available from: http://familydoctor.org/ 161.xml. Accessed November 28, 2020.

2. Siegel RL, Miller KD, Fuchs HE, et al. Cancer statistics, 2021 [published correction appears in CA Cancer J Clin. 2021 Jul;71(4):359]. CA Cancer J Clin. 2021;71(1):7-33. doi:10.3322/caac.21654

3. Santarpia M, Liguori A, Karachaliou N, et al. Osimertinib in the treatment of non-small-cell lung cancer: design, development and place in therapy. Lung Cancer Targets Ther. 2017;8:109-125. doi:10.2147/LCTT.S119644

4. Jurišić V, Obradovic J, Pavlović S, Djordjevic N. Epidermal growth factor receptor gene in non-small-cell lung cancer: the importance of promoter polymorphism investigation. Anal Cell Pathol. 2018;2018:6192187. doi:10.1155/2018/6192187

5. Schiller JH, Harrington D, Belani CP, et al. Comparison of four chemotherapy regimens for advanced non-small-cell lung cancer. N Engl J Med. 2002;346(2):92-98. doi:10.1056/NEJMoa011954

6. Mok TS, Wu YL, Thongprasert S, et al. Gefitinib or carboplatinpaclitaxel in pulmonary adenocarcinoma. $N$ Engl $J \mathrm{Med}$. 2009;361(10):947-957. doi:10.1056/nejmoa0810699

7. Maemondo M, Inoue A, Kobayashi K. Gefitinib or chemotherapy for non-small-cell lung cancer with mutated EGFR. $N$ Engl J Med. 2010;362(25):2380-2388. doi:10.1056/NEJMoa090953027

8. Zhou C, Wu YL, Chen G, et al. Erlotinib versus chemotherapy as first-line treatment for patients with advanced EGFR mutation-positive non-small-cell lung cancer (OPTIMAL, CTONG- 0802): a multicentre, open-label, randomised, phase 3 study. Lancet Oncol. 2011;12(8):735-742. doi:10.1016/S14702045(11)70184-X31

9. Zhou C, Wu YL, Chen G, et al. Final overall survival results from a randomised, Phase III study of erlotinib versus chemotherapy as first-line treatment of EGFR mutation-positive advanced non-small-cell lung cancer (OPTIMAL, CTONG-0802). Ann Oncol. 2015;26(9):1877-1883. doi:10.1093/annonc/mdv27632

10. Vyse S, Huang PH. Targeting EGFR exon 20 insertion mutations in non-small cell lung cancer. Signal Transduct Target Ther. 2019;4(1). doi:10.1038/s41392-019-0038-9

11. Steuer CE, Behera M, Berry L, et al. The role of race in oncogenic driver prevalence and outcomes in lung adenocarcinoma: results from the lung cancer mutation consortium. Cancer. 2016;122:766-772. doi:10.1002/cncr.29812

12. Tian YI, Zhao J, Ren P, et al. Different subtypes of EGFR exon19 mutation can affect prognosis of patients with non-small cell lung adenocarcinoma. PLoS One. 2018;13:e0201682. doi:10.1371/ journal.pone. 0201682

13. Fukuoka $\mathrm{M}, \mathrm{Wu} \mathrm{YL}$, Thongprasert $\mathrm{S}$, et al. Biomarker analyses and final overall survival results from a Phase III, randomized, open-label, first-line study of gefitinib versus carboplatin/paclitaxel in clinically selected patients with advanced non-small-cell lung cancer in Asia (IPASS). $J$ Clin Oncol. 2011;29 (21):2866-2874. doi:10.1200/JCO.2010.33.4235

14. Mitsudomi T, Morita S, Yatabe Y, West Japan Oncology Group. Gefitinib versus cisplatin plus docetaxel in patients with non-small-cell lung cancer harbouring mutations of the epidermal growth factor receptor (WJTOG3405): an open label, randomised Phase 3 trial. Lancet Oncol. 2010;11(2):121-128. doi:10.1016/ S1470-2045(09)70364-X

15. Yoshioka H, Mitsudomi T, Morita S, et al. Final overall survival results of WJTOG 3405, a randomized phase 3 trial comparing gefitinib (G) with cisplatin plus docetaxel (CD) as the first-line treatment for patients with non-small cell lung cancer (NSCLC) harboring mutations of the epidermal growth factor receptor (EGFR). J Clin Oncol. 2014;32(15_suppl):8117. doi:10.1200/ jco.2014.32.15_suppl.811729 
16. Han JY, Park K, Kim SW, et al. First-SIGNAL: first-line single-agent iressa versus gemcitabine and cisplatin trial in never-smokers with adenocarcinoma of the lung. J Clin Oncol. 2012;30(10):1122-1128. doi:10.1200/JCO.2011.36.8456

17. Rosell R, Carcereny E, Gervais R, for Spanish Lung Cancer Group in collaboration with Groupe Français de PneumoCancérologie and Associazione Italiana Oncologia Toracica. Erlotinib versus standard chemotherapy as first-line treatment for European patients with advanced EGFR mutation-positive non-small-cell lung cancer (EURTAC): a multicentre, open-label, randomised phase 3 trial. Lancet Oncol. 2012;13 (3):239-246. doi:10.1016/S1470-2045(11)70393-X

18. Wu YL, Zhou C, Liam CK, et al. First-line erlotinib versus gemcitabine/cisplatin in patients with advanced EGFR mutation-positive non-small-cell lung cancer: analyses from the phase III, randomized, open-label, ENSURE study. Ann Oncol. 2015;26(9):1883-1889. doi:10.1093/annonc/mdv27033

19. Hirsh V, Cadranel J, Cong XJ, et al. Symptom and quality of life benefit of afatinib in advanced non-small-cell lung cancer patients previously treated with erlotinib or gefitinib: results of a randomized phase IIb/III trial (LUX-Lung 1). J Thorac Oncol. 2013;8(2):229-237. doi:10.1097/JTO.0b013e3182773fce34

20. Sequest L, Yang J, Yamamoto N, et al. Phase III study of afatinib or cisplatin plus pemetrexed in patients with metastatic lung adenocarcinoma with EGFR mutations. J Clin Oncol. 2013;31 (27):3327-3334. doi:10.1200/JCO.2012.44.280635

21. Wu Y, Zhou $\mathrm{C}, \mathrm{Hu} \mathrm{CP}$, et al. Afatinib versus cisplatin plus gemcitabine for first-line treatment of Asian patients with advanced non-small-cell lung cancer harbouring EGFR mutations (LUX-Lung 6): an open-label, randomized phase 3 trial. Lancet Oncol. 2014;15(2):213-222. doi:10.1016/S1470-2045(13)70604136

22. Park K, Tan EH, O'Byrne K, et al. Afatinib versus gefitinib as first-line treatment of patients with EGFR mutation-positive non-small-cell lung cancer (LUX-Lung 7): a phase 2B, open-label, randomized controlled trial. Lancet Oncol. 2016;17 (5):577-589. doi:10.1016/S1470-2045(16)30033-X

23. Paz-Ares L, Tan EH, O'Byrne K, et al. Afatinib versus gefitinib in patients with EGFR mutation-positive advanced non-small-cell lung cancer: overall survival data from the phase IIb LUX-Lung 7 trial. Ann Oncol. 2017;28(2):270-277. doi:10.1093/annonc/ mdw61138

24. Soria JC, Felip E, Cobo M, et al. Afatinib versus erlotinib as second-line treatment of patients with advanced squamous cell carcinoma of the lung (LUX-Lung 8): an open-label randomized controlled phase 3 trial. Lancet Oncol. 2015;16(8):907-987. doi:10.1016/S1470-2045(15)00006-6

25. Wu YL, Cheng Y, Zhou X, et al. Dacomitinib versus gefitinib as first-line treatment for patients with EGFR-mutation-positive non-small-cell lung cancer (ARCHER 1050): a randomized, open-label, phase 3 trial. Lancet Oncol. 2017;18(11):1454-1466. doi:10.1016/S1470-2045(17)30608-3

26. Mok TS, Cheng Y, Zhou X, et al. Improvement in overall survival in a randomized study that compared dacomitinib with gefitinib in patients with advanced non-small-cell lung cancer and EGFRactivating mutations. J Clin Oncol. 2018;22:2244-2250. doi:10. 1200/JCO.2018.78.799441

27. Ramalingam SS, Janne PA, Mok T, et al. Dacomitinib versus erlotinib in patients with advanced stage, previously treated non-small cell lung cancer (ARCHER 1009): a randomized, double-blind, phase 3 trial. Lancet Oncol. 2014;15(12):13 69-1378. doi:10.1016/S1470-2045(14)70452-8

28. Mok TS, Wu YL, Ahn MJ, et al. Osimertinib or platinum-pemetrex in EGFR T790M-positive lung cancer. $N$ Engl J Med. 2017;376(7):629-640. doi:10.1056/NEJMoa1612 67443
29. Soria JC, Ohe Y, Vansteenkiste J, et al. Osimertinib in untreated EGFR-mutated advanced non-small-cell lung cancer. $N$ Engl J Med. 2018;378(2):113-125. doi:10.1056/NEJMoa171313744

30. Shi Y, Zhang L, Liu X, et al. Icotinib versus gefitinib in previously treated advanced non-small cell lung cancer (ICOGEN): a randomized, double-blind phase 3 non-inferiority trial. Lancet Oncol. 2013;13(10):953-961. doi:10.1016/S1470-2045(13) 70355-3

31. Shi YK, Wang L, Han BH, et al. First-line icotinib versus cisplatin/pemetrexed plus pemetrexed maintenance therapy for patients with advanced EGFR mutation-positive lung adenocarcinoma (CONVINCE): a phase 3, open-label, randomized study. Ann Oncol. 2017;28(10):2443-2450.46. doi:10.1093/annonc/mdx359

32. Lee CS, Sharma S, Miao E, Mensah C, Sullivan K, Seetharamu N. A comprehensive review of contemporary literature for epidermal growth factor receptor tyrosine kinase inhibitors in non-small cell lung cancer and their toxicity. Lung Cancer. 2020;11:73-103. doi:10.2147/LCTT.S258444

33. U.S. Food and Drug Administration. Hematology/oncology (cancer) approvals \& safety notifications; 2021. Available from: https:/www.fda.gov/drugs/resources-information-approved-drugs /hematologyoncology-cancer-approvals-safety-notifications. Accessed April 30, 2021.

34. U.S. Food and Drug Administration. Hematology/oncology (cancer) approvals \& safety notifications; 2021. Available from: http:// wayback.archive-it.org/7993/20170111064250/http://www.fda. gov/Drugs/InformationOnDrugs/ApprovedDrugs/ucm 279174. htm. Accessed April 30, 2021

35. Yang JJ, Zhou Q, Yan HH, et al. A phase III randomised controlled trial of erlotinib vs gefitinib in advanced non-small cell lung cancer with EGFR mutations. Br J Cancer. 2017;116 (5):568-574. doi:10.1038/bjc.2016.456

36. Suda K, Onozato R, Yatabe Y, Mitsudomi T. EGFR T790M mutation: a double role in lung cancer cell survival? J Thorac Oncol. 2009;4(1):1-4. doi:10.1097/JTO.0b013e3181913c9f

37. Ricciuti B, Baglivo S, Paglialunga L, et al. Osimertinib in patients with advanced epidermal growth factor receptor T790M mutation-positive non-small cell lung cancer: rationale, evidence and place in therapy. Ther Adv Med Oncol. 2017;9(6):387-403. doi: $10.1177 / 1758834017702820$

38. Eide IJZ, Helland A, Ekman S, et al. Osimertinib in T790M-positive and -negative patients with EGFR-mutated advanced non-small cell lung cancer (the TREM-study). Lung Cancer. 2020;143:27-35. doi:10.1016/j.lungcan.2020.03.009

39. Ramalingam SS, Vansteenkiste J, Planchard D, et al. Overall survival with osimertinib in untreated, EGFR -mutated advanced NSCLC. $N$ Engl J Med. 2020;382(1):41-50. doi:10.1056/ NEJMoa1913662

40. Chi A, Komaki R. Treatment of brain metastasis from lung cancer. Cancers. 2010;2:2100-2137. doi:10.3390/cancers204 2100

41. Li YS, Jiang BY, Yang JJ, et al. Leptomeningeal metastases in patients with NSCLC with EGFR mutations. J Thorac Oncol. 2016;11(11):1962-1969. doi:10.1016/j.jtho.2016.06.029

42. Ameku K, Higa M. Complete remission of multiple brain metastases in a patient with EGFR-mutated non-small-cell lung cancer treated with first-line osimertinib without radiotherapy. Case Rep Oncol Med. 2020;2020. doi:10.1155/2020/9076168

43. Varrone A, Varnäs K, Jucaite A, et al. A PET study in healthy subjects of brain exposure of 11C-labelled osimertinib - a drug intended for treatment of brain metastases in non-small cell lung cancer. J Cereb Blood Flow Metab. 2020;40(4):799-807. doi:10. 1177/0271678X19843776

44. Soria J-C, Ohe Y, Vansteenkiste J, et al. Osimertinib in untreated EGFR -mutated advanced non-small-cell lung cancer. $N$ Engl $J$ Med. 2018;378(2):113-125. doi:10.1056/nejmoa1713137 
45. Yang JCH, Ahn MJ, Kim DW, et al. Osimertinib in pretreated T790M-positive advanced non-small-cell lung cancer: AURA study Phase II extension component. J Clin Oncol. 2017;35 (12):1288-1296. doi:10.1200/JCO.2016.70.3223

46. Yang JCH, Kim SW, Kim DW, et al. Osimertinib in patients with epidermal growth factor receptor mutation-positive non-small-cell lung cancer and leptomeningeal metastases: the BLOOM study. J Clin Oncol. 2020;38(6):538-547. doi:10.1200/JCO.19.00457

47. Xing L, Pan Y, Shi Y, et al. Biomarkers of osimertinib response in patients with refractory, EGFR-T790M-positive non-small cell lung cancer and central nervous system metastases: the APOLLO study. Clin Cancer Res. 2020;26:6168-6175. doi:10.1158/1078-0432.CCR-20-2081

48. Ameku K, Higa M. Complete remission of multiple brain metastases in a patient with EGFR -mutated non-small-cell lung cancer treated with first-line osimertinib without radiotherapy. Case Rep Oncol Med. 2020;2020:1-6. doi:10.1155/2020/9076168

49. Wu YL, Herbst RS, Mann H, Rukazenkov Y, Marotti M, Tsuboi M. ADAURA: phase III, double-blind, randomized study of osimertinib versus placebo in EGFR mutation-positive early-stage NSCLC after complete surgical resection. Clin Lung Cancer. 2018;19(4):e533-e536. doi:10.1016/j.cllc.2018.04.004

50. Wu YL, Tsuboi M, He J, et al. Osimertinib in resected EGFR mutated non-small-cell lung cancer. $N$ Engl J Med. 2020;383 (18):1711-1723. doi:10.1056/nejmoa2027071

51. Pignon JP, Tribodet H, Scagliotti GV, et al. Lung adjuvant cisplatin evaluation: a pooled analysis by the LACE collaborative group. J Clin Oncol. 2008;26(21):3552-3559. doi:10.1200/ JCO.2007.13.9030

52. Zhong WZ, Wang Q, Mao WM, et al. Gefitinib versus vinorelbine plus cisplatin as adjuvant treatment for stage II-IIIA (N1-N2) EGFR-mutant NSCLC (ADJUVANT/ CTONG1104): a randomised, open-label, phase 3 study. Lancet Oncol. 2018;19:139-148. doi:10.1016/S1470-2045(17)30729-5

53. Zhong WZ, Wang Q, Mao WM, et al. Gefitinib versus vinorelbine plus cisplatin as adjuvant treatment for stage II-IIIA (N1-N2) EGFR-mutant NSCLC: final overall survival analysis of CTONG1104 phase III trial. J Clin Oncol. 2021;39(7):713-722. doi:10.1200/JCO.20.01820

54. Fang W, Huang Y, Hong S, et al. EGFR exon 20 insertion mutations and response to osimertinib in non-small-cell lung cancer. $B M C$ Cancer. 2019;19(1):595. doi:10.1186/s12885-019-5820-0

55. Robichaux JP, Elamin YY, Tan Z, et al. Mechanisms and clinical activity of an EGFR and HER2 exon 20-selective kinase inhibitor in non-small cell lung cancer. Nat Med. 2018;24(5):638-646. doi:10.1038/s41591-018-0007-9

56. Hirano T, Yasuda $H$, Tani $T$, et al. In vitro modeling to determine mutation specificity of EGFR tyrosine kinase inhibitors against clinically relevant EGFR mutants in non-small-cell lung cancer. Oncotarget. 2015;6(36):38789-38803. doi:10.18632/oncotarget. 5887

57. Yang M, Xu X, Cai J, Ning J, Wery JP, Li QX. NSCLC harboring EGFR exon-20 insertions after the regulatory C-helix of kinase domain responds poorly to known EGFR inhibitors. Int $J$ Cancer. 2016;139(1):171-176. doi:10.1002/ijc.30047

58. Piotrowska Z, Wang Y, Sequist LV, Ramalingam SS. ECOGACRIN 5162: a phase II study of osimertinib $160 \mathrm{mg}$ in NSCLC with EGFR exon 20 insertions. J Clin Oncol. 2020;38 (15_suppl):9513. doi:10.1200/jco.2020.38.15_suppl.9513

59. Cho JH, Lim SH, An HJ, et al. Osimertinib for patients with non-small-cell lung cancer harboring uncommon EGFR mutations: a multicenter, open-label, phase II trial (KCSG-LU15-09). J Clin Oncol. 2020;38(5):488-495. doi:10.1200/JCO.19.00931

60. Lazzari C, Gregorc V, Karachaliou N, Rosell R, Santarpia M. Mechanisms of resistance to osimertinib. J Thorac Dis. 2020;12 (5):2851-2858. doi:10.21037/jtd.2019.08.30
61. Leonetti A, Sharma S, Minari R, Perego P, Giovannetti E, Tiseo M. Resistance mechanisms to osimertinib in EGFR-mutated non-small cell lung cancer. $\mathrm{Br} J$ Cancer. 2019;121(9):725-737. doi:10.1038/s41416-019-0573-8

62. Tan CS, Kumarakulasinghe NB, Huang YQ, et al. Third generation EGFR TKIs: current data and future directions. Mol Cancer. 2018;17(1):29. doi:10.1186/s12943-018-0778-0

63. Hopp M. AFAMOSI: prospective, randomized, multicenter phase IV study to evaluate the efficacy and safety of afatinib followed by osimertinib compared to osimertinib in patients with EGFRmutated/T790M mutation negative non-squamous NSCLC in the first-line setting. NLM identifier: NCT04413201; Available from: http://www.clinicaltrials.gov/ct2/show/NCT03755102. Accessed May 10, 2021.

64. Case Comprehensive Cancer Center. Phase 1 trial of osimertinib with stereotactic radiosurgery (SRS) in patients with brain metastases from EGFR positive non-small-cell lung cancer (NSCLC). NLM identifier: NCT03535363; Available from: http://www.clinicaltrials.gov/ct2/show/NCT03535363. Accessed May 10, 2021.

65. University of Texas Southwestern Medical Center. Phase II trial of osimertinib in combination with stereotactic ablative radiation (SABR) in EGFR mutant advanced non-small cell lung cancer (NSCLC). NLM identifier: NCT03667820; Available from: http:// www.clinicaltrials.gov/ct2/show/NCT03667820. Accessed May 10, 2021.

66. First Affiliated Hospital of Zhejiang University. A prospective, national, multi-centric, non-interventional study of first line osimertinib in chinese patients with locally advanced/ metastatic, EGFR mutation-positive NSCLC in real world setting. NLM identifier: NCT04391283; Available from: http://www. clinicaltrials.gov/ct2/show/NCT04391283. Accessed May 10, 2021.

67. First Affiliated Hospital of Zhejiang University. A prospective, multi-center, interventional study of osimertinib combined with anlotinib in acquired EGFR T790M mutated NSCLC patients with gradual progression on osimertinib treatment. NLM identifier: NCT04438902; Available from: http://www.clinicaltrials. gov/ct2/show/NCT04438902. Accessed May 10, 2021.

68. Seoul National University Hospital. Whole genomic landscape of EGFR mutation-positive advanced non-small cell lung cancer treated with first-line osimertinib (WARRIOR). NLM identifier: NCT03969823; Available from: http://www.clinicaltrials.gov/ct2/ show/NCT03969823. Accessed May 10, 2021.

69. Samsung Medical Center. A phase II, open-label, single-arm, multicenter, efficacy and safety of $80 \mathrm{mg}$ osimertinib in patients with leptomeningeal metastases(LM) associated with EGFR mutation-positive non-small cell lung cancer(NSCLC). NLM identifier: NCT04563871; Available from: http://www.clinical trials.gov/ct2/show/NCT04563871. Accessed May 10, 2021.

70. Trans-Tasman Radiation Oncology Group (TROG). A randomised phase II trial of osimertinib with or without stereotactic radiosurgery for EGFR mutated non-small cell lung cancer (NSCLC) with brain metastases. NLM identifier: NCT03497767; Available from: http://www.clinicaltrials.gov/ct2/show/ NCT03497767. Accessed May 10, 2021.

71. Dana-Farber Cancer Institute. A phase $1 / 2$ study of osimertinib in combination with gefitinib in EGFR inhibitor naïve advanced EGFR mutant lung cancer. NLM identifier: NCT03122717; Available from: http://www.clinicaltrials.gov/ct2/show/ NCT03122717. Accessed May 10, 2021.

72. AstraZeneca. Osimertinib plus savolitinib in EGFRm+/MET+ NSCLC following prior osimertinib (SAVANNAH). NLM identifier: NCT03778229; Available from: https://clinicaltrials.gov/ct2/ show/NCT03778229. Accessed May 10, 2021. 
73. Daping Hospital and the Research Institute of Surgery of the Third Military Medical University. Prospective observational trial to evaluate the efficacy of the combination of osimertinib and aspirin in patients with disease progression to 1st generation EGFR-TKI due to acquisition of EGFR T790M. NLM identifier: NCT03543683; Available from: http://www.clinicaltrials.gov/ct2/ show/NCT03543683. Accessed May 10, 2021.

74. Academisch Ziekenhuis Maastricht. Pharmacokinetic boosting of osimertinib (OSIBOOST). NLM identifier: NCT03858491; Available from: https://clinicaltrials.gov/ct2/show/ NCT03858491. Accessed May 10, 2021.

75. EMD Serono Research \& Development Institute, Inc. A study of tepotinib plus osimertinib in osimertinib relapsed MET amplified NSCLC (INSIGHT 2). NLM identifier: NCT03940703; Available from: https://clinicaltrials.gov/ct2/show/NCT03940703. Accessed May 10, 2021.

76. AstraZeneca. A phase III, open-label, randomized study of osimertinib with or without platinum plus pemetrexed chemo, as first-line treatment in patients with epidermal growth factor receptor (EGFR) mutation positive, locally advanced or metastatic non-small cell lung cancer (FLAURA2). NLM identifier: NCT04035486; Available from: http://www.clinicaltrials.gov/ct2/ show/NCT04035486. Accessed May 10, 2021.

77. Dana-Farber Cancer Institute. A phase 2 study of osimertinib in combination with selumetinib in EGFR inhibitor naïve advanced EGFR mutant lung cancer. NLM identifier: NCT03392246; Available from: http://www.clinicaltrials.gov/ct2/show/ NCT03392246. Accessed May 10, 2021.

78. Massachusetts General Hospital. Phase 1 study of niraparib in combination with osimertinib in EGFR-mutated advanced lung cancer. NLM identifier: NCT03891615; Available from: http:// www.clinicaltrials.gov/ct2/show/NCT03891615. Accessed May 10,2021

79. Daping Hospital and the Research Institute of Surgery of the Third Military Medical University. Prospective observational trial to evaluate the efficacy of the combination of osimertinib and aspirin in patients with epidermal growth factor receptor(EGFR)-mutation. NLM identifier: NCT04184921; Available from: http://www.clinicaltrials.gov/ct2/show/ NCT04184921. Accessed May 10, 2021.

80. Daping Hospital and the Research Institute of Surgery of the Third Military Medical University. Combination of osimertinib and aspirin to treat osimertinib resistance non-small cell lung cancer (NSCLC). NLM identifier: NCT03532698; Available from: https:// clinicaltrials.gov/ct2/show/NCT03532698. Accessed May 10, 2021.

81. Intergroupe Francophone de Cancerologie Thoracique. Study of osimertinib in patients with a lung cancer with brain or leptomeningeal metastases with EGFR mutation (ORBITAL). NLM identifier: NCT04233021; Available from: https://clinicaltrials.gov/ ct2/show/NCT04233021. Accessed May 10, 2021.

82. British Columbia Cancer Agency. Study of osimertinib + SRS vs osimertinib alone for brain metastases in EGFR positive patients with NSCLC. NLM identifier: NCT03769103; Available from: https://clinicaltrials.gov/ct2/show/NCT03769103. Accessed May 10, 2021.

83. Samsung Medical Center. Osimertinib to suppress the progression of GGN(EGFR mutation-positive). NLM identifier: NCT04591002; Available from: https:/clinicaltrials.gov/ct2/ show/NCT04591002. Accessed May 10, 2021.

84. Le X. Study of osimertinib with and without ramucirumab in locally advanced or metastatic non-small cell lung cancer (NSCLC). NLM identifier: NCT03909334; Available from: https://clinicaltrials.gov/ct2/show/NCT03909334. Accessed May 10, 2021.
85. Ascentage Pharma Group Inc. A study of APG-1252 plus osimertinib(AZD9291) in EGFR TKI resistant NSCLC patients. NLM identifier: NCT04001777; Available from: https://clinicaltrials. gov/ct2/show/NCT04001777. Accessed May 20, 2021.

86. Memorial Sloan Kettering Cancer Center. Study of dacomitinib and osimertinib for patients with advanced EGFR mutant lung cancer. NLM identifier: NCT03810807; Available from: https://clinical trials.gov/ct2/show/NCT03810807.Accessed May 10, 2021.

87. Daiichi Sankyo, Inc. DS-1205c with osimertinib for metastatic or unresectable epidermal growth factor receptor (EGFR)-mutant non-small cell lung cancer. NLM indentifier: NCT03255083; Available from: https://clinicaltrials.gov/ct2/show/ NCT03255083. Accessed May 10, 2021.

88. Genprex, Inc. TUSC2-nanoparticles (GPX-001) and osimertinib in patients with stage IV lung cancer who progressed on osimertinib alone. NLM identifier: NCT04486833; Available from: https://clin icaltrials.gov/ct2/show/NCT04486833. Accessed May 10, 2021.

89. Duke University. A study osimertinib in patients with stage 4 non-small cell lung cancer with uncommon EGFR mutations. NLM identifier: NCT03434418; Available from: https://clinical trials.gov/ct2/show/NCT03434418. Accessed May 10, 2021.

90. Memorial Sloan Kettering Cancer Center. Osimertinib and bevacizumab as treatment for EGFR-mutant lung cancers. NLM identifier: NCT02803203; Available from: https://clinicaltrials. gov/ct2/show/NCT02803203. Accessed May 10, 2021.

91. AstraZeneca. A global study to assess the effects of osimertinib following chemoradiation in patients with stage III unresectable non-small cell lung cancer (LAURA). NLM identifier: NCT03521154; Available from: https://clinicaltrials.gov/ct2/ show/NCT03521154. Accessed May 10, 2021.

92. University of California, San Francisco. Osimertinib in treating participants with stage I-IIIA EGFR-mutant non-small cell lung cancer before surgery. NLM identifier: NCT03433469; Available from: https://clinicaltrials.gov/ct2/show/NCT03433469. Accessed May 10, 2021.

93. Revolution Medicines, Inc. Dose-escalation/expansion of RMC-4630 and cobimetinib in relapsed/refractory solid tumors and RMC-4630 and osimertinib in EGFR positive locally advanced/metastatic NSCLC. NLM identifier: NCT03989115. Available from: https:/clinicaltrials.gov/ct2/show/ NCT03989115. Accessed May 10, 2021.

94. European Thoracic Oncology Platform. Osimertinib and bevacizumab versus osimertinib alone as second-line treatment in stage IIIb-IVb NSCLC with confirmed EGFRm and T790M (BOOSTER) (BOOSTER). NLM identifier: NCT03133546; Available from: https://clinicaltrials.gov/ct2/show/ NCT03133546. Accessed May 10, 2021.

95. Blakely $\mathrm{C}$ Alisertib in combination with osimertinib in metastatic EGFR-mutant lung cancer. NLM identifier: NCT04085315; Available from: https://clinicaltrials.gov/ct2/show/ NCT04085315. Accessed May 10, 2021.

96. Seoul National University Hospital. Osimertinib for NSCLC with EGFR exon 20 insertion mutation. NLM identifier: NCT034 14814; Available from: https://clinicaltrials.gov/ct2/show/ NCT03414814. Accessed May 10, 2021.

97. AstraZeneca. A study of osimertinib with or without chemotherapy versus chemotherapy alone as neoadjuvant therapy for patients with EGFRm positive resectable non-small cell lung cancer (NeoADAURA). NLM identifier: NCT04351555; Available from: https://clinicaltrials.gov/ct2/show/ NCT04351555. Accessed May 10, 2021.

98. Memorial Sloan Kettering Cancer Center. A study of the combination of osimertinib, platinum and etoposide for patients with metastatic EGFR mutant lung cancers. NLM identifier: NCT03567642; Available from: https://clinicaltrials.gov/ct2/ show/NCT03567642. Accessed May 10, 2021. 
99. M.D. Anderson Cancer Center. Osimertinib in combination with alisertib or sapanisertib for the treatment of osimertinib-resistant EGFR mutant stage IIIB or IV non-small cell lung cancer. NLM identifier: NCT04479306; Available from: https://clinicaltrials.gov/ct2/show/ NCT04479306. Accessed May 10, 2021.

100. National Cancer Institute (NCI). Osimertinib and necitumumab in treating patients with EGFR-mutant stage IV or recurrent non-small cell lung cancer who have progressed on a previous EGFR tyrosine kinase inhibitor. NLM identifier: NCT02496663; Available from: https://clinicaltrials.gov/ct2/show/NCT02496663. Accessed May 10, 2021.

101. National Cancer Institute (NCI). Telaglenastat hydrochloride and osimertinib in treating patients with EGFR-mutated stage IV non-small cell lung cancer. NLM identifier: NCT03831932; Available from: https:/clinicaltrials.gov/ct2/show/ NCT03831932. Accessed May 10, 2021.

102. Kim C. Dasatinib and osimertinib (AZD9291) in advanced non-small cell lung cancer with EGFR mutations. NLM identifier: NCT02954523; Available from: https://clinicaltrials.gov/ct2/ show/NCT02954523. Accessed May 10, 2021.

103. Second Affiliated Hospital of Nanchang University. Osimertinib with bevacizumab for leptomeningeal metastasis from EGFR-mutation non-small cell lung cancer (OWBLM). NLM identifier: NCT04425681; Available from: https://clinicaltrials. gov/ct2/show/NCT04425681. Accessed May 10, 2021.

104. Second Affiliated Hospital of Nanchang University. Osimertinib with or without bevacizumab for EGFR- mutant non-small cell lung cancer with leptomeningeal metastasis (OWONBNSCLCLM). NLM identifier: NCT04148898; Available from: https://clinicaltrials.gov/ct2/show/ NCT04148898. Accessed May 10, 2021.

105. Soroka University Medical Center. Intracranial activity of AZD9291 (TAGRISSO) in advanced EGFRm NSCLC patients with asymptomatic brain metastasessor. NLM identifier: NCT02736513; Available from: https://clinicaltrials.gov/ct2/ show/NCT02736513. Accessed May 10, 2021.

106. AstraZeneca. A study comparing savolitinib plus osimertinib vs savolitinib plus placebo in patients with EGFRm+ and MET amplified advanced NSCLC (CoC). NLM identifier: NCT04606771; Available from: https://clinicaltrials.gov/ct2/ show/NCT04606771. Accessed May 10, 2021.

107. Memorial Sloan Kettering Cancer Center. Osimertinib alone or with chemotherapy for EGFR-mutant lung cancers. NLM identifier: NCT04410796; Available from: https://clinicaltrials.gov/ct2/ show/NCT04410796. Accessed May 10, 2021.

108. University of Utah. PhIb study evaluating safety and efficacy of combination osimertinib and ipilimumab in patients w EGFR mutated NSCLC (Osi+Ipi). NLM identifier: NCT04141644; Available from: https://clinicaltrials.gov/ct2/show/ NCT04141644. Accessed May 10, 2021.

109. National Cancer Institute (NCI). AZD9291 (osimertinib) with or without bevacizumab as initial treatment for patients with EGFR-mutant lung cancer. NLM identifier: NCT04181060. Available from: https:/clinicaltrials.gov/ct2/show/ NCT04181060. Accessed May 10, 2021.

110. G1 Therapeutics, Inc. G1T38, a CDK $4 / 6$ inhibitor, in combination with osimertinib in EGFR-mutant non-small cell lung cancer. NLM identifier: NCT03455829; Available from: https:// clinicaltrials.gov/ct2/show/NCT03455829. Accessed May 10, 2021.

111. Vincent M. Osimertinib then chemotherapy in EGFR-mutated lung cancer with osimertinib third-line rechallenge (OCELOT). NLM identifier: NCT04335292; Available from: https://clinicaltrials.gov/ct2/show/NCT04335292. Accessed May 10, 2021.
112. National Cancer Institute (NCI). Testing the combination of MLN0128 (TAK-228) and AZD9291 in advanced EGFR (epidermal growth factor receptor) mutation positive non-small cell lung cancer. NLM identifier: NCT02503722; Available from: https:// clinicaltrials.gov/ct2/show/NCT02503722. Accessed May 10, 2021.

113. University of California, San Diego. Osimertinib and abemaciclib in EGFR mutant non-small cell lung cancer after osimertinib resistance. NLM identifier: NCT04545710; Available from: https://clinicaltrials.gov/ct2/show/NCT04545710. Accessed May 10, 2021.

114. National Cancer Institute (NCI). Osimertinib and navitoclax in treating patients with EGFR-positive previously treated advanced or metastatic non-small cell lung cancer. NLM identifier: NCT02520778; Available from: https://clinicaltrials.gov/ct2/ show/NCT02520778. Accessed May 10, 2021.

115. Soroka University Medical Center. Neo-adjuvant trial with AZD9291 in EGFRm+ stage IIIA/B NSCLC. NLM identifier: NCT02824952; Available from: https://clinicaltrials.gov/ct2/ show/NCT02824952. Accessed May 10, 2021.

116. Incyte Corporation. An open-label phase $1 / 2$ study of itacitinib in combination with osimertinib in subjects with non-small cell lung cancer. NLM identifier: NCT02917993; Available from: https:// clinicaltrials.gov/ct2/show/NCT02917993. Accessed May 10, 2021.

117. Tianjin Medical University Cancer Institute and Hospital. Study of anlotinib combined with osimertinib as second-line treatment in stage IIIb-IV NSCLC with confirmed EGFRm and T790M (ALTN-03). NLM identifier: NCT04029350; Available from: https:/clinicaltrials.gov/ct2/show/NCT04029350. Accessed May 10, 2021.

118. Eli Lilly and Company. A study of ramucirumab (LY3009806) or necitumumab (LY3012211) plus osimertinib in participants with lung cancer. NLM identifier: NCT02789345; Available from: https://clinicaltrials.gov/ct2/show/NCT02789345. Accessed May 10, 2021.

119. The Netherlands Cancer Institute. T-DM1 and osimertinib combination treatment to target HER2 bypass track resistance in EGFR mutation positive NSCLC (TRAEMOS). NLM identifier: NCT03784599; Available from: https://clinicaltrials.gov/ct2/ show/NCT03784599. Accessed May 10, 2021.

120. National Cancer Institute (NCI). Osimertinib with or without bevacizumab in treating patients with EGFR positive non-small cell lung cancer and brain metastases. NLM identifier: NCT02971501; Available from: https://clinicaltrials.gov/ct2/ show/NCT02971501. Accessed May 10, 2021.

121. M.D. Anderson Cancer Center. Osimertinib, surgery, and radiation therapy in treating patients with stage IIIB or IV non-small cell lung cancer with EGFR mutations, NORTHSTAR study. NLM identifier: NCT03410043; Available from: https://clinical trials.gov/ct2/show/NCT03410043. Accessed May 10, 2021.

122. Jonsson Comprehensive Cancer Center. Necitumumab and trastuzumab in combination with osimertinib for the treatment of refractory epidermal growth factor receptor (EGFR)-mutated stage IV non-small cell lung cancer. NLM identifier: NCT04285671; Available from: https://clinicaltrials.gov/ct2/ show/NCT04285671. Accessed May 10, 2021.

123. Janssen Research \& Development, LLC. A study of amivantamab and lazertinib combination therapy versus osimertinib in locally advanced or metastatic non-small cell lung cancer (MARIPOSA). NLM identifier: NCT04487080; Available from: https:/clinical trials.gov/ct2/show/NCT04487080. Accessed May 10, 2021.

124. Haihe Biopharma Co., Ltd. Glumetinib combined with osimertinib in the treatment of relapsed and metastatic non-small cell lung cancer patients who failed to receive EGFR inhibitors. NLM identifier: NCT04338243; Available from: https://clinicaltrials. gov/ct2/show/NCT04338243. Accessed May 10, 2021. 
125. Memorial Sloan Kettering Cancer Center. A pilot study of dacomitinib with or without osimertinib for patients with metastatic EGFR mutant lung cancers with disease progression on osimertinib. NLM identifier: NCT03755102; Available from: https://clinicaltrials.gov/ct2/show/NCT03755102. Accessed May $10,2021$.

126. Takeda. A study of TAK-788 in Japanese adults with non-small cell lung cancer. NLM identifier: NCT03807778; Available from: https:/clinicaltrials.gov/ct2/show/NCT03807778. Accessed May 10, 2021.

127. British Columbia Cancer Agency. Study of osimertinib + SRS vs osimertinib alone for brain metastases in EGFR positive patients with NSCLC. NLM identifier: NCT03769103; Available from: https://clinicaltrials.gov/ct2/show/NCT03769103. Accessed May $10,2021$.

128. Millennium Pharmaceuticals, Inc. TAK-788 as first-line treatment versus platinum-based chemotherapy for non-small cell lung cancer (NSCLC) with EGFR exon 20 insertion mutations. NLM identifier: NCT04129502; Available from: https://clinicaltrials.gov/ct2/show/NCT04129502. Accessed May 10, 2021
129. Millennium Pharmaceuticals, Inc. A trial of TAK-788 (AP32788) in non-small cell lung cancer (NSCLC). NLM identifier: NCT02716116; Available from: https://clinicaltrials.gov/ct2/ show/NCT02716116. Accessed May 10, 2021.

130. Memorial Sloan Kettering Cancer Center. A pilot study of dacomitinib with or without osimertinib for patients with metastatic EGFR mutant lung cancers with disease progression on osimertinib. NLM identifier: NCT03755102; Available from: https://clinicaltrials.gov/ ct2/show/NCT03755102. Accessed May 10, 2021.

131. Sequist LV, Han JY, Ahn MJ, et al. Osimertinib plus savolitinib in patients with EGFR mutation-positive, MET-amplified, non-small-cell lung cancer after progression on EGFR tyrosine kinase inhibitors: interim results from a multicentre, open-label, phase 1b study. Lancet Oncol. 2020;21(3):373-386. doi:10.1016/ S1470-2045(19)30785-5

132. Akamatsu H, Toi Y, Hayashi H, et al. Efficacy of osimertinib plus bevacizumab vs osimertinib in patients with EGFR T790M-mutated non-small cell lung cancer previously treated with epidermal growth factor receptor-tyrosine kinase inhibitor: West Japan oncology group 8715L phase 2 randomized clinical trial. JAMA Oncol. 2021;7 (3):386-394. doi:10.1001/jamaoncol.2020.6758

\section{Publish your work in this journal}

OncoTargets and Therapy is an international, peer-reviewed, open access journal focusing on the pathological basis of all cancers, potential targets for therapy and treatment protocols employed to improve the management of cancer patients. The journal also focuses on the impact of management programs and new therapeutic agents and protocols on patient perspectives such as quality of life, adherence and satisfaction. The manuscript management system is completely online and includes a very quick and fair peer-review system, which is all easy to use. Visit http://www.dovepress.com/ testimonials.php to read real quotes from published authors. 